DOE/AL/62350-209

REV. 0

\title{
BASELINE RISK ASSESSMENT OF Ground Water Contamination at THE URANIUM MiLl TAILINGS Site Near Maybell, Colorado
}

September 1995

\section{DISCLAIMER}

This report was prepared as an account of work sponsored by an agency of the United States Government. Neither the United States Government nor any agency thereof, nor any of their employees, makes any warranty, express or implied, or assumes any legal liability or responsibility for the accuracy, completeness, or usefulness of any information, apparatus, product, or process disclosed, or represents that its use would not infringe privately owned rights. Reference herein to any specific commercial product, process, or service by trade name, trademark, manufacturer, or otherwise does not necessarily constitute or imply its endorsement, recommendation, or favoring by the United States Government or any agency thereof. The views and opinions of authors expressed herein do not necessarily state or reflect those of the United States Government or any agency thereof.

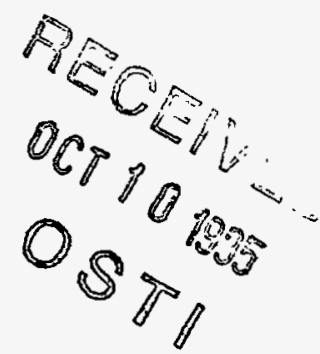

DISTAIBUTION OF THIS DOCUMENT IS UNLIMITED NIT)

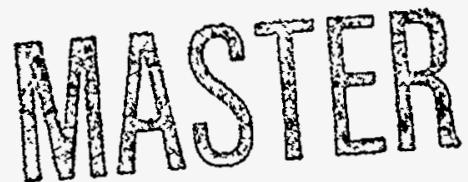




\section{INTENDED FOR PUBLIC RELEASE}

This report has been reproduced from the best available copy. Available in paper copy and microfiche

Number of pages in this report: 60

DOE and DOE contractors can obtain copies of this report from:

Office of Scientific and Technical Information

P.O. Box 62

Oak Ridge, TN 37831

(615) 576-8401

This report is publicly available from:

National Technical Information Service

Department of Commerce

5285 Port Royal Road

Springfield, VA 22161

(703) $487-4650$ 


\section{DISCLAIMER}

Portions of this document may be illegible in electronic image products. Images are produced from the best available original document. 
REV. 0

BASELINE RISK ASSESSMENT OF GROUND WATER CONTAMINATION AT THE URANIUM MILL TAILINGS SITE

NEAR MAYBELL, COLORADO

\section{September 1995}

Prepared for

U.S. Department of Energy

Environmental Restoration Division UMTRA Project Team

Albuquerque, New Mexico

Prepared by Jacobs Engineering Group Inc.

Albuquerque, New Mexico 



\section{CITIZEN'S SUMMARY}

The U.S. Department of Energy (DOE) Uranium Mill Tailings Remedial Action (UMTRA) Project consists of the Surface Project (Phase I) and the Ground Water Project (Phase II). Under the UMTRA Surface Project, tailings, radioactive contaminated soil, building foundations, and materials associated with the former processing of uranium ore at UMTRA sites are placed into disposal cells. The cells are designed to reduce radon and other radiation emissions and to prevent further contamination of ground water. One UMTRA Project site is near Maybell, Colorado. Surface cleanup at this site is under way and is scheduled for completion in 1996. The tailings are being stabilized in-place at this site. The disposal area has been withdrawn from public use by the DOE and is referred to as the permanent withdrawal area.

The Ground Water Project evaluates the nature and extent of ground water contamination resulting from past uranium ore processing activities. The Ground Water Project at this site is in its beginning stages. This report is a site-specific document that will be used to evaluate current and future potential impacts to the public and the environment from exposure to contaminated ground water. The results of this evaluation and further site characterization will determine whether any action is needed to protect human health or the environment.

A risk assessment describes a source of contamination, how that contamination reaches the environment, the amount of contamination to which people and ecological communities (which are the receptors) may be exposed, and the health or environmental effects that could result from that exposure. This assessment differs from other UMTRA site baseline risk assessments because a quantitative assessment of human health and ecological risks is not presented. The rationale to support the decision not to perform a quantitative risk assessment is presented in this document.

\section{RISK SUMMARY}

Currently, no points of exposure (e.g. a drinking water well); and no receptors of contaminated ground water have been identified at the Maybell site. Therefore, there are no current human health and ecological risks associated with exposure to contaminated ground water. Furthermore, if current site conditions and land-and water-use patterns do not change, it is unlikely that contaminated ground water would reach people or the ecological communities in the future.

\section{GROUND WATER QUALITY AND USES}

\section{Background ground water quality}

The Maybell uranium district contains many uranium deposits. Because the area was widely mined in the past, the potential for natural and man-made sources of uranium and related contaminants in the vicinity of the Maybell site is great. Background water quality is defined as the quality of ground water that would be present at the site if uranium milling activities had not taken place. In the vicinity of the Maybell site, background 
ground water quality is naturally contaminated due to uranium ore deposits and, therefore, is classified as limited use ground water.

\section{Site-related ground water quality}

There is one water-producing unit beneath the Maybell site, the Browns Park Formation aquifer. Water used in the uranium processing activities at the Maybell site (from 1957 to 1964), moved down through the tailings and contaminated the aquifer with inorganic chemicals and radionuclides. The flow of contaminated ground water beneath the site is generally toward the southwest.

Site-related contaminants were determined by comparing background concentrations to concentrations of constituents in ground water directly beneath the tailings pile and processing site. The contaminants with concentrations above background are, aluminum, ammonium, cadmium, calcium, chloride, copper, fluoride, iron, magnesium, manganese, molybdenum, nitrate, phosphate, potassium, selenium, sodium, strontium, sulfate, uranium, zinc, lead-210, polonium-210, radium-226, and thorium-230.

Ground water quality in areas next to the tailings, but inside the permanent withdrawal area, and ground water quality from outside of the permanent withdrawal area were also compared to background concentrations. These comparisons indicate that the levels of contaminants that were added to ground water by uranium milling activities fall off sharply in areas next to the site. Concentrations of site-related contaminants outside of the permanent withdrawal area fall within the range of background levels. It has been almost 40 years since the milling operations began and more than 30 years since they ceased. It is possible that ground water chemical and physical reactions may be responsible for the absence of site-related contamination beyond a few hundred feet from the tailings pile. Regardless of the reason, ground water contamination has not moved beyond the immediate vicinity of the mill site and tailings pile since the processing began.

If current ground water conditions do not change, there is no reason to believe that the contaminants will be detected outside of the permanent withdrawal area at levels above background concentrations in the future. However, certain activities at the Maybell site could cause site ground water conditions to change. The surface cleanup construction activities (i.e., shaking, squeezing, and excavation of the tailings pile) could affect current ground water conditions by adding more water to the aquifer. The result of this is that contaminated ground water could move outside of the permanent withdrawal area and increase the contaminant concentrations in the aquifer. Currently, the magnitude of these changes has not been estimated, but modeling efforts are underway.

Currently, no residential, industrial/commercial, municipal, or agricultural wells have been identified within a 3 mile (5 kilometer) radius of the site. However, livestock wells, that no longer exist, have been known to be located in the area of the site. The closest surface water body to the Maybell site that could have the potential to be influenced by ground water from the site is Rob Pit. A local rancher uses the surface water in this pit as a livestock watering source. The pit could also be used for recreational purposes (for example, swimming), and by wildlife as a water source. Evaluation of surface water quality data from Rob Pit indicates that it has not been impacted by past uranium milling 
activities. However, the potential exists for surface water conditions to change in the future. That is, the additional water added to the aquifer because of construction activities could cause ground water from the site to move in the direction of the pit and contaminant concentrations could exceed background levels.

\section{CONCLUSIONS}

Currently, no human health or ecological risks are associated with the use of contaminated ground water at the Maybell site. This will continue if the use of water and land at the site, and current ground water conditions do not change. That is, if ground water contaminants from the site do not move outside of the permanent withdrawal area in concentrations above background levels, and no exposure pathways are completed.

However, if current ground water conditions at the site change in the future and concentrations of contaminants from the site exceed background levels outside of the permanent withdrawal area, livestock, people, and the ecological environment could potentially be exposed to contaminants. Nonetheless, because of the unique ground water conditions at the Maybell site (no off-site contamination has been observed) and the uncertainty associated with predicting future site ground water conditions, a quantitative risk is not presented. Assessing future scenarios using current information would not necessarily represent future site conditions. However, in order to assure that human health and the environment is adequately protected in the future, monitoring of the ground water should continue so that any changes in ground water conditions can be evaluated.

The environmental evaluation of the UMTRA Project Maybell site is ongoing and will include further characterization of ground water quality and movement. This risk assessment and future investigations will be used to determine how to comply with UMTRA ground water standards. 



\section{TABLE OF CONTENTS}

Section

Page

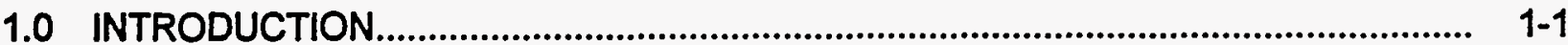

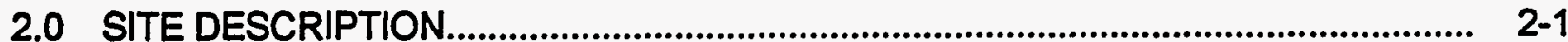

2.1 Site location and history ............................................................................ 2-1

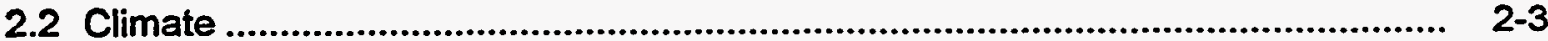

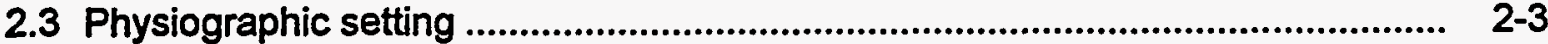

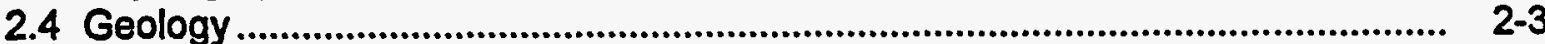

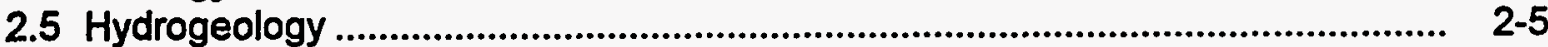

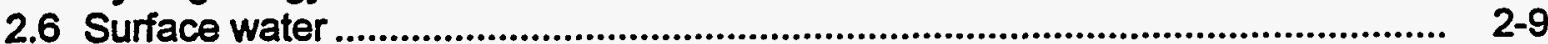

3.0 MAGNITUDE AND EXTENT OF CONTAMINATION............................................. $3-1$

3.1 Data sources and statistical methods ............................................................ $3-1$

3.2 Background water quality summary........................................................... $3-4$

3.3 Magnitude of site-related ground water contamination ....................................... 3-6

3.4 Surface water ............................................................................................... $3-16$

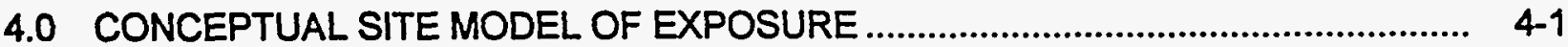

4.1 Contaminant transport scenarios..................................................................... 4-1

4.1.1 Potential impacts of surface remediation on ground water ..................... 4-1

4.2 Ground water and land use ............................................................................. 4-3

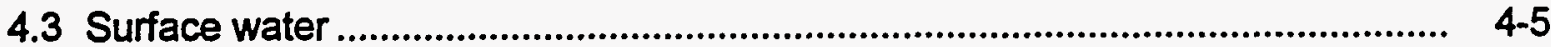

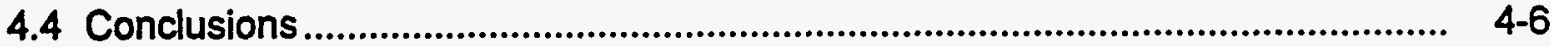

4.5 Limitations and datagaps...................................................................... 4-6

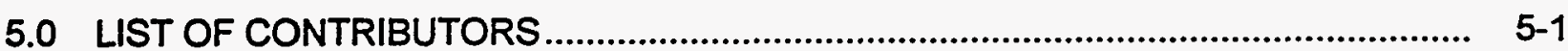

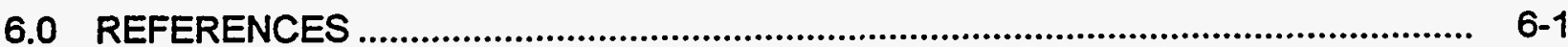




\section{LIST OF FIGURES}

Figure

Page

2.1 Tailings site location map Maybell, Colorado, site

2.2 Site boundaries, topography, mine locations and geologic structures,

Maybell, Colorado, site

2.3 Potentiometric surface map for the Browns Park Formation aquifer

Maybell, Colorado, site

2.4 Cross section of land surface and potentiometric surface, Maybell, Colorado, site

2.5 Surface water features and sampling locations, Maybell, Colorado, site

3.1 Trilinear plot showing major ion concentrations Maybell, Colorado, site

3.2 Highest observed nitrate and uranium concentrations in monitor wells, Maybell, Colorado.

4.1 Conceptual site model of exposure Maybell, Colorado, site

4.2 Approximate land ownership boundaries for areas surrounding the Maybell, Colorado, site 


\section{LIST OF TABLES}

Table

Page

3.1 Monitor well information, Maybell, Colorado, site

3.2 Constituents present above background concentrations under or near the tailings pile, Maybell, Colorado, site.

3.3 Ground water quality in the Brown's Park Formation, Maybell, Colorado site.......

3.4 Years sampled and number of data rounds available for surface sampling locations, Maybell, Colorado, site.

3.5 Results of analyses of surface water samples in Johnson Wash and Lay Creek for nitrate, sulfate, and uranium, Maybell, Colorado, site

3.6 Comparison of water quality in the unnamed background pit to Rob Pit, Maybell, Colorado site 


\section{LIST OF ACRONYMS}

\section{Acronym Definition}

$\begin{array}{ll}\text { ANOVA } & \text { analysis of variance } \\ \text { BLM } & \text { Bureau of Land Management } \\ \text { DOE } & \text { U.S. Department of Energy } \\ \text { LTSP } & \text { long term surveillance plan } \\ \text { MCL } & \text { maximum concentration level } \\ \text { MSL } & \text { mean sea level } \\ \text { RAP } & \text { remedial action plan } \\ \text { RRM } & \text { residual radioactive materials } \\ \text { UMTRA } & \text { Uranium Mill Tailings Remedial Action } \\ \text { UMTRCA } & \text { Uranium Mill Tailings Radiation Control Act }\end{array}$




\subsection{INTRODUCTION}

The former uranium mill tailings processing site near Maybell, Colorado (hereafter referred to as the Maybell site) is 1 of 24 designated uranium mill tailings sites that are undergoing surface remediation in accordance with the requirements of the Uranium Mill Tailings Radiation Control Act (UMTRCA) (42 USC $\$ 7901$ et seq.) under the oversight of the U.S. Department of Energy (DOE) Uranium Mill Tailings Remedial Action (UMTRA) Project. The designated site is the area originally established under the UMTRA Project that included the actual mill site and the tailings pile, and includes the potential source area for residual radioactive materials (RRM).

The UMTRA Project consists of the Surface Project and the Ground Water Project. Under the UMTRA Surface Project, tailings, radioactive contaminated soil, building foundations, and materials associated with the former processing of uranium ore at UMTRA sites are stabilized in disposal cells. The cells are designed to reduce radon and other radiation emissions and to prevent further contamination of ground water. Construction activities for surface remediation at the Maybell site began in the spring of 1995 and the disposal cell is scheduled to be completed during 1996. The tailings are being stabilized on the site. The permanent withdrawal area for the Maybell disposal site is comprised of 251 acres (ac) (101 hectares [hal) and will be fenced, effectively establishing a government controlled area that will be inaccessible to the public. Permanent withdrawal of public lands is allowed under Section 106 of the UMTRCA, as amended in the UMTRA Amendments Act of 1988 (42 USC $\$ 7922$ et seq.), to facilitate remediation of RRM. The size of the permanent withdrawal area is larger than the designated site in order to incorporate design features of the disposal cell.

The Ground Water Project evaluates the nature and extent of ground water contamination resulting from past uranium ore processing activities. Ground water underneath the tailings pile at the Maybell site was contaminated by the leaching of inorganic chemicals and radionuclides from the tailings pile. The DOE was authorized to conduct ground water remediation under the 1988 UMTRA Amendments Act and will determine site-specific ground water compliance strategies for each site. This report is one of the first Ground Water Project site-specific documents that provides information to assist the DOE in determining the site-specific ground water compliance strategy for the Maybell site and will support decisions made for the UMTRA Ground Water Project. Additional detail on the site is available in the surface Remedial Action Plan (RAP) (DOE, 1994a).

The purpose of this baseline risk assessment is to determine whether the contaminated ground water at the Maybell site could adversely affect human health or the environment. This assessment differs from other UMTRA site baseline risk assessments because a quantitative assessment of human health and ecological risks is not presented. The determination to not quantitatively evaluate potential risks is based on the geochemical and hydrogeological evaluation of the ground water contamination at this site, as well as the absence of current complete exposure pathways and the unlikeliness of a complete exposure pathway to occur in the future. 
This document presents the rationale to support the decision not to perform a quantitative risk assessment. In Section 2.0 the hydrogeologic setting of the Maybell site is presented. Section 3.0 presents the geochemical and statistical evaluation of the analytical data associated with the site, and Section 4.0 discusses the site conceptual model of potential exposure at the Maybell site, as well as the limitations and identified datagaps of this assessment. 


\subsection{SITE DESCRIPTION}

This section describes the history of the milling operations at the Maybell site, the regional climate, the physiography of the immediate area around the site, and key aspects of the geology and hydrogeology of the site that relate to ground water flow and contaminant transport. A brief description of surface waters and drainage features near the Maybell site is presented. An understanding of these elements provides the basis for this risk assessment.

\subsection{SITE LOCATION AND HISTORY}

The Maybell site is located 25 miles (mi) (40 kilometers [km]) west of Craig, Colorado, in Moffat County, in the northwestern part of the state. The unincorporated town of Maybell is located $5 \mathrm{mi}(8 \mathrm{~km})$ southwest of this site (Figure 2.1).

The Trace Elements Corporation established the Maybell, Colorado mill site in 1955 and 1956. The Union Carbide Corporation assumed control of the site and began operating the mill in 1957. Umetco Minerals Corporation, a whollyowned subsidiary of the Union Carbide Corporation, holds the radioactive materials license for the tailings site and continues as the operational controller. Uranium ore was obtained from nearby open pit mines. During 7 years of operation, the mill processed approximately 2.6 million tons $(2.4$ million metric tons) of ore, having a grade of 0.098 percent uranium oxide. The ore was processed using a resin-in-pulp acid leach method. An upgrader circuit at the processing plant treated low-grade ore prior to leaching. Water for the mill operations came from the Yampa River. It is estimated that about one million gallons of water were used per day for the operations. In the early 1960's, three settling ponds were constructed along the south edge of the tailings pile. All concentrate produced was sold to the U.S. Atomic Energy Commission.

There is insufficient detailed information about mill activities to determine the exact locations of contaminant sources. Mill effluent may have been placed on the tailings piles or may have been collected in the ponds close to the former mill buildings. In addition, monitor well coverage around the former mill buildings and near the settlement ponds, which are possible contaminant sources, does not reveal specific contaminant source locations.

After the mill shut down in November 1964, Umetco dismantled it and, in 1971, started stabilizing the tailings in accordance with the state of Colorado regulations. The remaining features include the tailings pile, foundation materials at the former mill processing site area, open pit mines, and overburden piles. The uranium milling processes used at this site are described in detail in Section 3.0. 
Figure 2.1

Tailings Site Location Map

Maybell, Colorado, Site
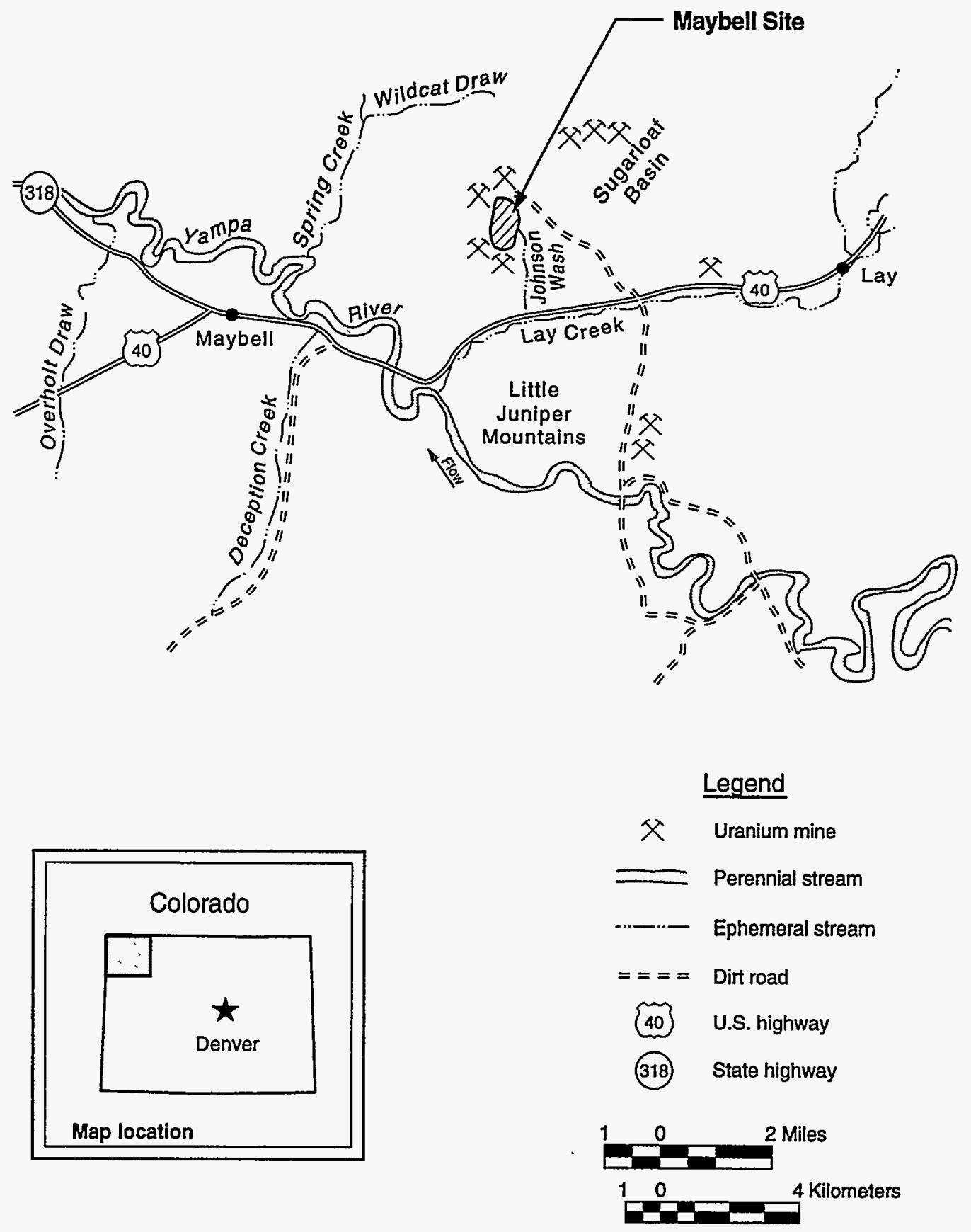
The designated site area, shown in Figure 2.2, covers approximately 110 ac (45 ha) and consists of a tailings pile and rubble from the demolition of the mill buildings buried in the former mill area. The site is situated between Johnson Wash to the east and Rob Pit to the west. Several reclaimed and unclaimed mines are in the immediate vicinity. Contaminated materials at the Maybell site include the tailings pile, which has an average depth of 20 feet $(\mathrm{ft})$ ( 6 meters [m]) and contains 2.8 million cubic yards $\left(\mathrm{yd}^{3}\right)\left(2.1\right.$ million cubic meters $\left[\mathrm{m}^{3} \mathrm{~J}\right)$ of tailings. The former mill processing area is on the north side of the site and contains $20,000 \mathrm{yd}^{3}\left(15,000 \mathrm{~m}^{3}\right)$ of contaminated demolition debris. Off-pile contamination is present and includes areas adjacent to the tailings pile, as well as contamination dispersed by wind and surface water flow. The volume of offpile contamination to be placed in the disposal cell is $550,000 \mathrm{yd}^{3}$ $\left(420,000 \mathrm{~m}^{3}\right)$. The total volume of contaminated materials to be disposed of as part of the remedial action is estimated to be 3.4 million $\mathrm{yd}^{3}\left(2.6\right.$ million $\left.^{3}\right)$.

\section{$2.2 \quad$ CLIMATE}

From 1959 through 1994, the average annual precipitation at the town of Maybell was 11.7 inches ( 29.7 centimeters [cm]) and was distributed relatively uniformly throughout the year (WRCC, 1995). The snowfall accumulation is approximately 65 inches $(170 \mathrm{~cm})$ per year and generally does not result in rapid runoff. Based on conditions at the Craig, Colorado, airport the prevailing winds are from the west southwest, and to a lesser degree from the east northeast. The prevailing wind at the tailings pile is toward the east and to a lesser degree north and south along Johnson Wash (URS Company, 1976).

The average maximum temperature in July is 86 degrees Fahrenheit $\left({ }^{\circ} \mathrm{F}\right)(30$ degrees Celsius $\left[{ }^{\circ} \mathrm{C}\right]$ ); the average minimum temperature in January is $1^{\circ} \mathrm{F}$ $\left(-17^{\circ} \mathrm{C}\right)$. Extreme temperatures recorded east of the site in Lay, Colorado, range from $101^{\circ} \mathrm{F}$ to $-47^{\circ} \mathrm{F}\left(38^{\circ} \mathrm{C}\right.$ to $\left.-44^{\circ} \mathrm{C}\right)$ (URS Company, 1976). Average annual pan evaporation in the area is 48 inches $(122 \mathrm{~cm}$ ) (NOAA, 1968).

\section{$2.3 \quad$ PHYSIOGRAPHIC SETTING}

The Maybell site is located in a small valley that is approximately $2.4 \mathrm{mi}$ ( 3.8 $\mathrm{km})$ long east to west and $2.0 \mathrm{mi}(3.2 \mathrm{~km})$ wide north to south. The center of this valley where the tailings pile is located is at an elevation of about $6200 \mathrm{ft}$ $(1900 \mathrm{~m})$ mean sea level (MSL). Hill tops around the valley reach elevations of as much as $400 \mathrm{ft}(120 \mathrm{~m})$ above the center of the valley. This valley is drained by Johnson Wash, an ephemeral stream, and its tributaries. The center of the valley is about $200 \mathrm{ft}(60 \mathrm{~m})$ above the Lay Creek Valley where Johnson Wash intersects Lay Creek (Figure 2.2).

\subsection{GEOLOGY}

At the Maybell site surficial deposits consist of colluvium mantled slopes and narrow alluvial deposits in gullies that feed Johnson Wash. These colluvial and 


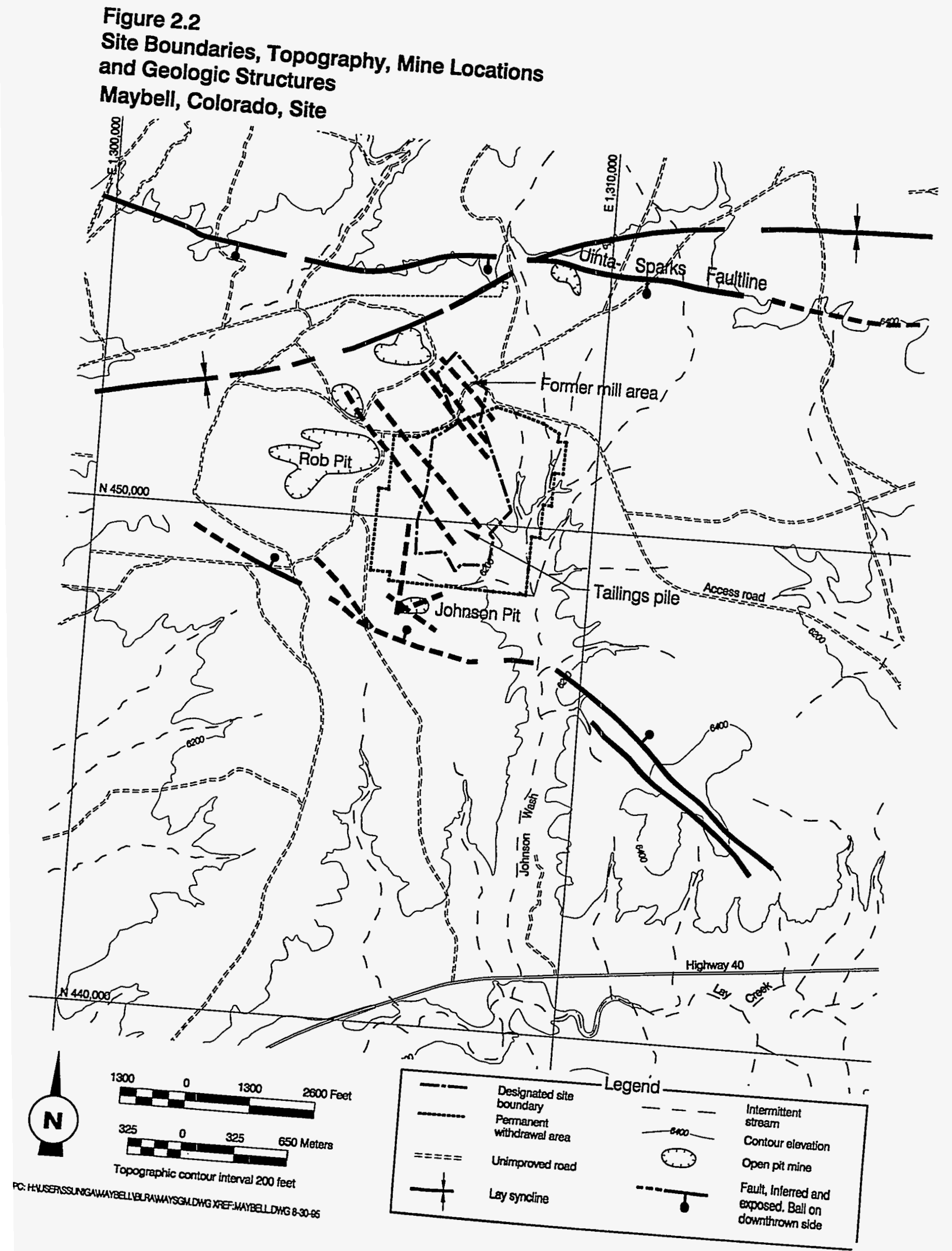


alluvial deposits are up to $25 \mathrm{ft}(8 \mathrm{~m})$ thick. Alluvial deposits are also present along Johnson Wash, Lay Creek and the Yampa River (DOE, 1994).

The Maybell site is underlain by the Tertiary Browns Park Formation of Miocene age, which unconformably overlies truncated rocks of the Cretaceous Mancos Shale. The beds of the Browns Park Formation generally dip less than 10 degrees to the north toward the east-west trending axis of the Lay Syncline, located north of the site (Figure 2.2). In this area, the Browns Park Formation consists of fluviolacustrine (river and lake deposited) and eolian (windblown) sandstones overlying a basal conglomerate (Chenoweth, 1986). The lower conglomerate unit ranges in thickness from 0 to $150 \mathrm{ft}(0$ to $45 \mathrm{~m})$. The upper sandstone unit (approximately $1000 \mathrm{ft}[300 \mathrm{~m}]$ thick) consists of tan to gray, fine- to medium-grained sandstone with minor interbeds and lenses of conglomerate, chert, siltstone, marlstone, and volcanic ash and pumice (commonly altered to clay). The tan sandstones, typical of the oxidized zone, are commonly stained with limonite/hematite and jarosite. The unoxidized gray sandstones contain finely divided pyrite. Depth to the top of the gray sandstones ranges from 40 to $240 \mathrm{ft}(12$ to $73 \mathrm{~m}$ ), which corresponds approximately to the first occurrence of ground water. The sandstone is generally weakly cemented above the water table, and is generally friable and uncemented below the water table. Occasional thin lenses are moderately hard with calcite and clay cementation.

Uranium deposits were discovered in the Maybell uranium district in 1953 (Chenoweth, 1986). Uranium mineralization generally occurs in the upper sandstone unit of the Browns Park Formation. The source of the uranium is believed to be volcanic ash beds in the Browns Park Formation. Hydrocarbons escaping from underlying Cretaceous formations and migrating upward through faults into the Browns Park Formation are postulated to have been important in creating reducing conditions necessary for precipitation of uranium (Figure 2.2) (Chenoweth, 1986). The Maybell District contains widespread low-grade uranium mineralization, where a number of open pit uranium mines supplied the Maybell site. These include Johnson Pit to the south, Rob Pit to the west, and several pits to the north and northeast (upstream/upgradient) of the millsite/tailings pile (Figures 2.2). The mineralized trend also extends south of U.S. Highway 40 and Lay Creek (Figure 2.1), with several open pit uranium mines (and prospects) in this area. The Maybell district has been extensively altered by exploration drilling and mining activities from the 1950 s until the 1970s. Therefore the potential for natural and man-made sources of uranium and related contaminants to impact ground water in the vicinity of the Maybell site is substantial.

\section{$2.5 \quad$ HYDROGEOLOGY}

Ground water occurs in the upper sandstone unit of the Browns Park Formation (uppermost aquifer) under unconfined conditions beneath the Maybell site. Water levels measured in monitor wells in the vicinity of the site range from 35 to over $300 \mathrm{ft}(11$ to $92 \mathrm{~m})$ beneath the surface. Fluctuations of ground water 
elevations were generally less than $2 \mathrm{ft}(0.6 \mathrm{~m}$ ) (from lowest to highest ground water elevation) during a period of measurement of over 3 years. These minor fluctuations are in response to temporal and spatial variation in precipitation and subsequent recharge of the aquifer.

Ground water also occurs in the alluvium associated with the Yampa River and Lay Creek. Ground water in the Yampa River Valley alluvium is unconfined and ranges in depth from 10 to $20 \mathrm{ft}(3$ to $6 \mathrm{~m})$ below land surface. Based upon ground water elevations projected from the potentiometric surface of the Browns Park Formation, it appears that the Yampa River Valley alluvium is recharged by ground water from the Browns Park Formation.

Ground water beneath the Maybell site is recharged from a limited upslope catchment basin. Recharge is principally from infiltration of precipitation in the form of rain or snow.

The potentiometric surface map of the upper Browns Park Formation aquifer indicates that ground water flow direction is generally toward the southwest beneath the site, with a hydraulic gradient of approximately 0.02 (Figure 2.3; DOE, 1994). A ground water mound appears to exist beneath and upgradient of the tailings pile and is very likely the result of tailings seepage recharging the water table. At the edges of the mound, the hydraulic gradient is steeper than the regional hydraulic gradient. A cross section with surface topography and the potentiometric surface shows this apparent ground water mound near the tailings pile (Figure 2.4).

Aquifer pumping tests were conducted in four monitor wells (MAY-01-0662, $-0663,-0665$, and -0672 ) to measure hydraulic parameters of the upper portion of the Browns Park Formation at the Maybell tailings pile (DOE, 1994). (Note: All well numbers in this report include the prefix "MAY-01-0." For ease of reading, this prefix is cited only in tables.) Results indicated unconfined conditions with delayed yield during the latter stages of the tests. Calculations based on pumping test data from the four monitor wells indicated an arithmetic mean for transmissivity of 92 square feet $\left(\mathrm{ft}^{2}\right)$ per day $(0.99$ square centimeters $\left[\mathrm{cm}^{2}\right]$ per second). The average hydraulic conductivity of the upper sandstone unit was estimated to be $1.7 \mathrm{ft}$ per day $\left(6.0 \times 10^{-4} \mathrm{~cm}\right.$ per second). Aquifer testing of the Browns Park Formation conducted in 1959 by Trace Elements Corporation yielded hydraulic conductivity values between $11.4 \mathrm{ft}$ per day $14.0 \times$ $10^{-3} \mathrm{~cm}$ per second) and $17.0 \mathrm{ft}$ per day $\left(6.0 \times 10^{-3} \mathrm{~cm}\right.$ per second) (Dames and Moore, 1975). These values are in the upper range of hydraulic conductivity values for a sandstone (Freeze and Cherry, 1979).

The average linear ground water velocity in the upper sandstone unit of the Browns Park Formation was estimated based on the most representative values (generally averaged) available from hydrogeologic characterization data for the site. The average linear ground water velocity was $0.17 \mathrm{ft}$ per day $16 \times 10^{-5} \mathrm{~cm}$ per second), based on an average hydraulic conductivity of $1.7 \mathrm{ft}$ per day $\left(6 \times 10^{-4} \mathrm{~cm}\right.$ per second) (derived from pumping test data), an average hydraulic 


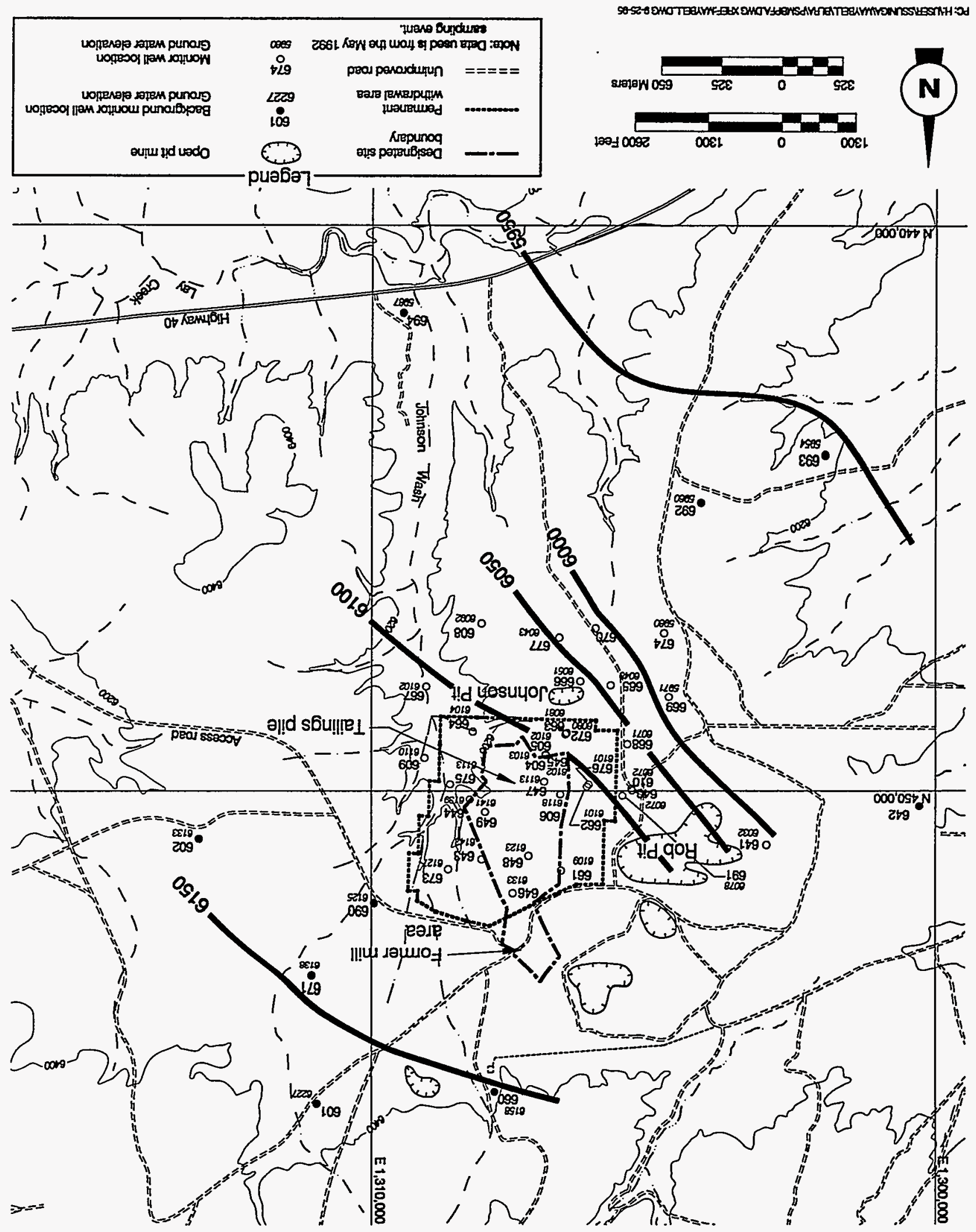

әџS 'оредоро "

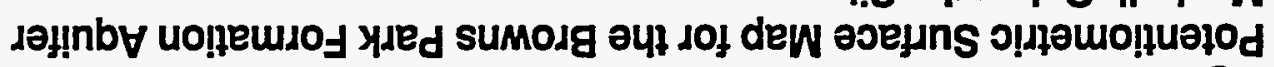

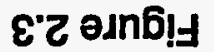


Figure 2.4

Cross Section of Land Surface and Potentiometric Surface

Maybell, Colorado, Site

Elevation in meters (msl)

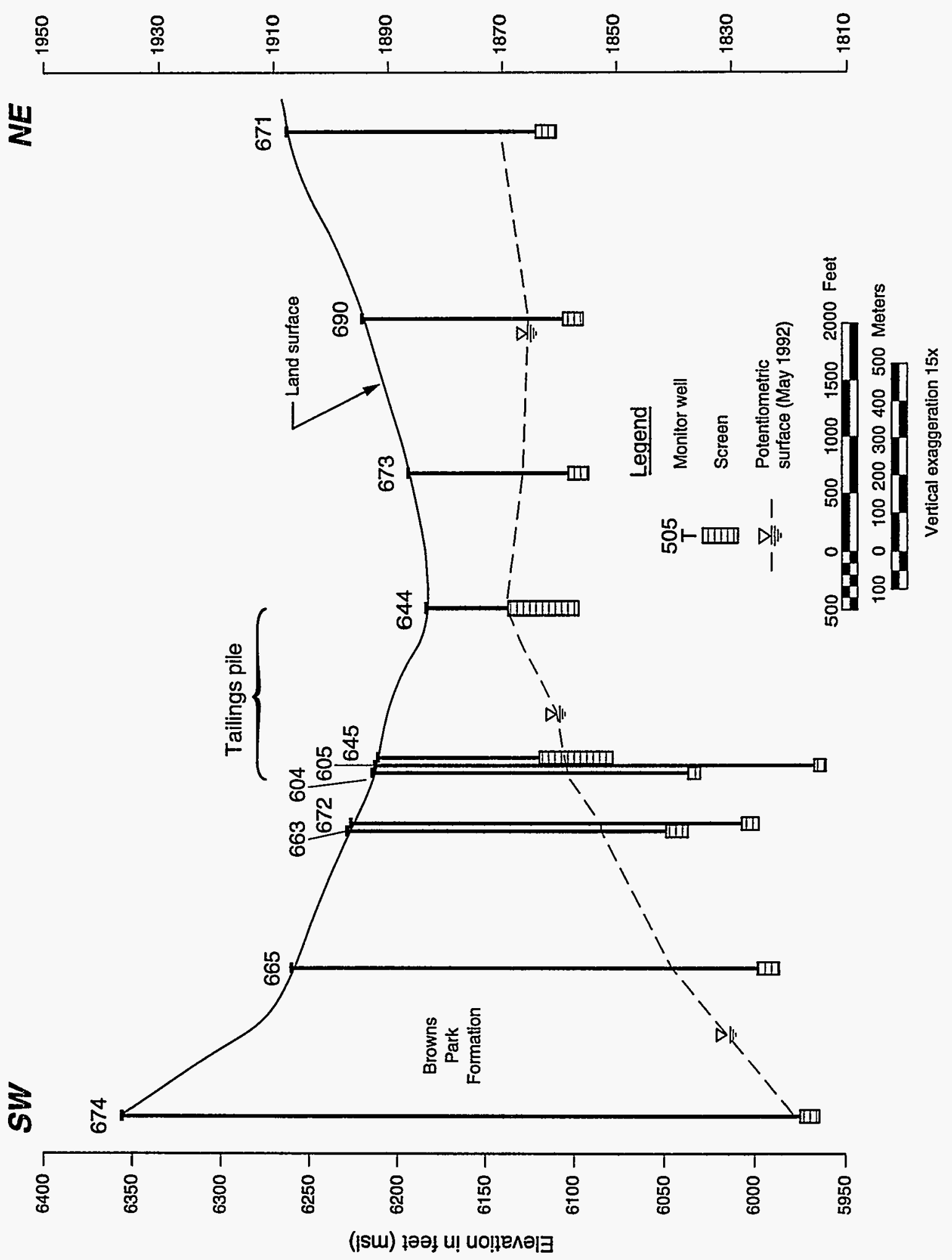


gradient of 0.02 (from potentiometric surface map), and an estimated effective porosity of 0.20 (Calculation MAY-11-93-14-07-00, DOE, 1994). Using a value of $0.17 \mathrm{ft}$ per day $\left(6 \times 10^{-5} \mathrm{~cm}\right.$ per second), or $62.0 \mathrm{ft}$ per year $(18.9 \mathrm{~m}$ per year), for an average linear ground water velocity, ground water would have moved horizontally about $1900 \mathrm{ft}(580 \mathrm{~m})$ downgradient since 1964 when the mill was shut down.

\subsection{SURFACE WATER}

Johnson Wash, an ephemeral stream, drains the Maybell site and nearby areas and flows only during major runoff events. Johnson Wash is a tributary to Lay Creek, which is another ephemeral stream. The confluence of Johnson Wash with Lay Creek is $1.5 \mathrm{mi}(2.4 \mathrm{~km})$ south of the site and $200 \mathrm{ft}(60 \mathrm{~m})$ lower in elevation than the base of the tailings pile (Figure 2.5). The bottom of Johnson Wash could intersect the water table at certain intervals. A seep (701) in Johnson Wash about $1000 \mathrm{ft}(300 \mathrm{~m})$ north of Lay Creek is very likely an expression of ground water. Seep 719, farther up the wash, may be the result of surface runoff that has infiltrated into the alluvium, but is perched above the more impermeable Browns Park Formation. Because of the distance of these seeps from the tailings pile and direction of ground water flow across the site, it is not likely that contamination in ground water beneath the tailings pile could reach the surface through these seeps.

The surface body of water nearest the Maybell site is in the bottom of Rob Pit, approximately $0.3 \mathrm{mi}(0.5 \mathrm{~km})$ west of the tailings pile. The water surface elevation in Rob Pit corresponds to the water table elevation in the area. Because ground water flows radially away from the ground water mound beneath the tailings pile, there is some component of flow from the mound toward Rob Pit. It is possible that contaminants in ground water beneath the tailings pile could eventually reach Rob Pit. Surface water also occurs in the bottom of another open pit mine near Sugarloaf Basin approximately $2 \mathrm{mi}(3 \mathrm{~km})$ east of the Maybell site. The relationship of water in this pit to the ground water table is not known. 
Figure 2.5

Surface Water Features and Sampling Locations Maybell, Colorado, Site

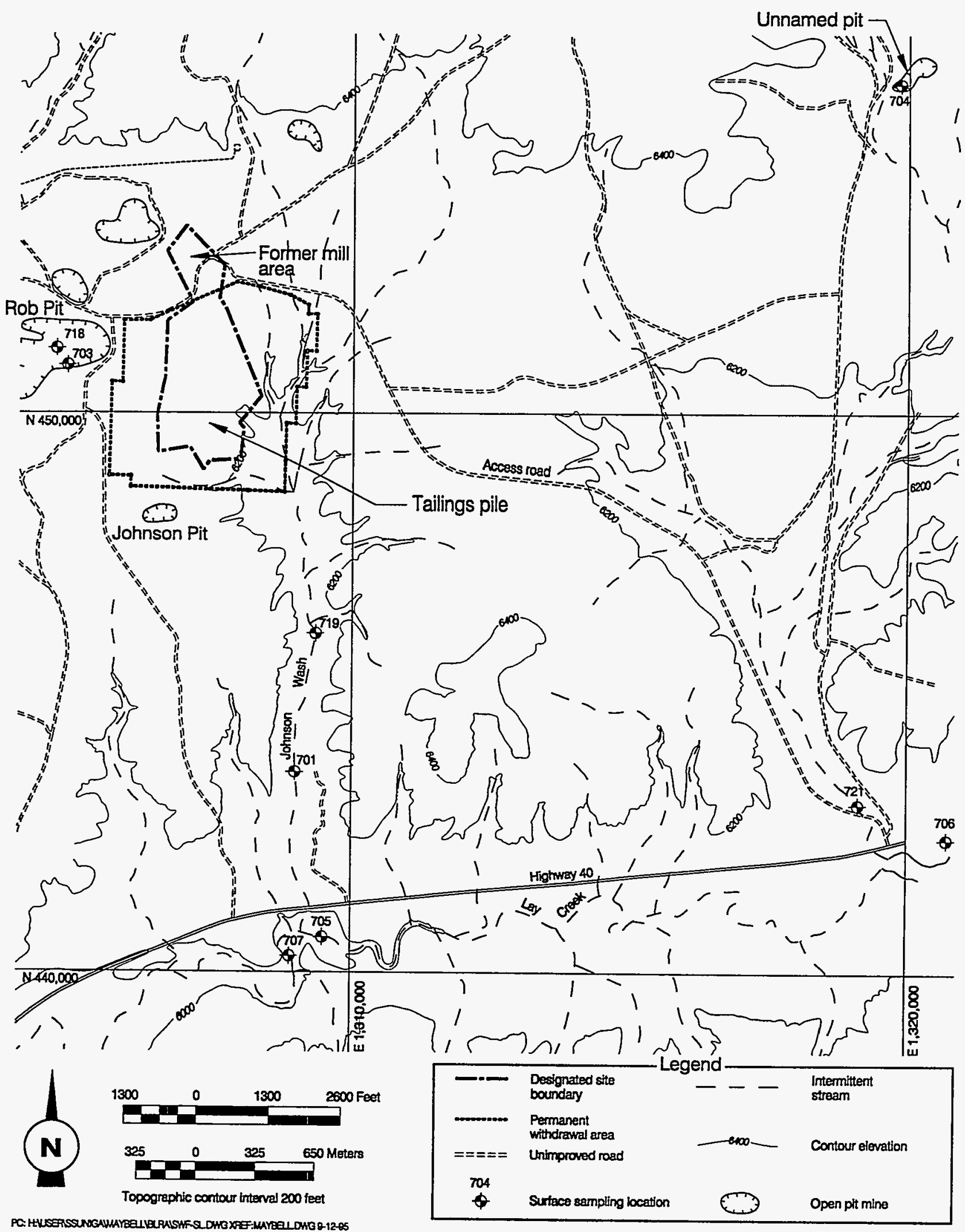




\subsection{MAGNITUDE AND EXTENT OF CONTAMINATION}

The purpose of this section is to delineate the area where processing-related ground water contamination exists, to identify site-contaminants, and to estimate the amount of contamination that exists in ground water as a result of former uranium processing activities at the Maybell site. This information is used to develop the conceptual site model of exposure for the Maybell site.

\subsection{DATA SOURCES AND STATISTICAL METHODS}

Ground water quality data from the Maybell site collected from 1986 to 1995 were used to characterize the magnitude and extent of contamination (TAC, 1995a). A total of 44 DOE monitor wells and 6 private wells were sampled. Figure 2.3 presents a map of the Maybell site showing the DOE monitor well network. Table 3.1 gives the sampling history and screen interval for each well. All wells were completed in the Browns Park Formation.

Data from filtered ground water samples were used to evaluate site-related ground water contamination because only one round of data from unfiltered ground water samples is available for the Maybell site. In August, 1992, both filtered and unfiltered ground water samples were collected from some of the monitor wells at the site and analyzed for a limited number of inorganic constituents. The 1992 results suggest that the following constituents may be higher in unfiltered than in filtered ground water: aluminum, iron, lead, manganese, silica, uranium, vanadium, and zinc.

In 1988 and 1989, ground water from three monitor wells $(643,645$, and 648) at the Maybell site was screened for organic constituents listed in Appendix IX to 40 CFR Part 264. There were no organic constituents detected in 1988. In 1989 small amounts of carbon disulfide and toluene (18 and 19 micrograms per liter respectively) were detected in ground water from monitor well 643 , directly beneath the pile. There is no information to indicate that these chemicals were used during uranium processing at the site.

Statistical methods were employed to identify constituents in ground water that are elevated above ambient levels as a result of contamination added to the ground water from former uranium processing activities at the site (TAC, 1995a). Concentrations of constituents in ground water from nine monitor wells completed directly beneath the tailings pile and processing site (locations $606,643,644,646,647,648,649,661$ and 673) were compared to concentrations of constituents found in eight background ground water wells (locations 601, 602, 660, 671, 690, 692, 693, and 694). Well locations are found on Figure 2.3. Measurements from the selected wells were ranked from 1 = smallest to $N=$ largest, and then the average rankings of the wells were compared using analysis of variance (ANOVA). The results of the procedure approximate those of the Kruskal-Wallis nonparametric test when applied to data sets with more than 30 observations (EPA, 1989). Data sets analyzed for 
Table 3.1 Monitor well information, Maybell, Colorado, site

\begin{tabular}{|c|c|c|c|}
\hline Monitor well ID & Years sampled & Number of sampling rounds & $\begin{array}{c}\text { Screen interval } \\
\text { (ft) }\end{array}$ \\
\hline \multicolumn{4}{|l|}{ Background wells } \\
\hline \multicolumn{4}{|l|}{ Upgradient } \\
\hline $\begin{array}{l}\text { MAY-01-601 } \\
\text { MAY-01-602 } \\
\text { MAY-01-660 } \\
\text { MAY-01-671 } \\
\text { MAY-01-690 }\end{array}$ & $\begin{array}{c}86-92,94 \\
86-92,94-95 \\
89-92,95 \\
89-92 \\
87-92,94-95\end{array}$ & $\begin{array}{c}9 \\
12 \\
6 \\
5 \\
9\end{array}$ & $\begin{array}{l}147-152 \\
156-161 \\
280-290 \\
140-150 \\
115-125\end{array}$ \\
\hline \multicolumn{4}{|l|}{ Far Downgradient } \\
\hline $\begin{array}{l}\text { MAY-01-692 } \\
\text { MAY-01-693 } \\
\text { MAY-01-694 }\end{array}$ & $\begin{array}{c}87-90,92 \\
87-92 \\
87-92\end{array}$ & $\begin{array}{l}6 \\
7 \\
7\end{array}$ & $\begin{array}{c}340-350 \\
281-296 \\
61-76\end{array}$ \\
\hline \multicolumn{4}{|l|}{ Inside Withdrawal Area } \\
\hline $\begin{array}{l}\text { MAY-01-606 } \\
\text { MAY-01-643 } \\
\text { MAY-01-644 } \\
\text { MAY-01-646 } \\
\text { MAY-01-647 } \\
\text { MAY-01-648 } \\
\text { MAY-01-649 } \\
\text { MAY-01-661 }\end{array}$ & $\begin{array}{c}86-92,94-95 \\
86-92 \\
86-92 \\
86-92 \\
86-92 \\
86-90,92 \\
86-92 \\
89-92,94-95\end{array}$ & $\begin{array}{l}11 \\
9 \\
9 \\
9 \\
9 \\
8 \\
9 \\
7\end{array}$ & $\begin{array}{c}122-137 \\
48-88 \\
43-83 \\
98-138 \\
\text { NA } \\
\text { NA } \\
\text { NA } \\
140-150\end{array}$ \\
\hline \multicolumn{4}{|l|}{ Adiacent to the site } \\
\hline $\begin{array}{l}\text { MAY-01-604 } \\
\text { MAY-01-605 } \\
\text { MAY-01-662 } \\
\text { MAY-01-663 } \\
\text { MAY-01-664 } \\
\text { MAY-01-672 } \\
\text { MAY-01-673 } \\
\text { MAY-01-675 } \\
\text { MAY-01-676 } \\
\text { MAY-01-695 } \\
\text { MAY-01-696 }\end{array}$ & $\begin{array}{c}86-92,94-95 \\
86-92,94-95 \\
89-92 \\
89-92,94-95 \\
89-92 \\
89-92 \\
89-92,94-95 \\
89-92,95 \\
89-92,94-95 \\
94-95 \\
94-95\end{array}$ & $\begin{array}{l}12 \\
12 \\
5 \\
7 \\
5 \\
5 \\
7 \\
6 \\
7 \\
2 \\
2\end{array}$ & $\begin{array}{c}177-182 \\
242-247 \\
180-190 \\
180-189 \\
130-139 \\
220-230 \\
90-100 \\
100-110 \\
150-159 \\
130-150 \\
148-168\end{array}$ \\
\hline
\end{tabular}


Table 3.1 Monitor well information, Maybell, Colorado, site (Concluded)

\begin{tabular}{lccc}
\hline \multicolumn{1}{c}{ Monitor well ID } & Years sampled & Number of sampling rounds & $\begin{array}{c}\text { Screen interval } \\
\text { (ft) }\end{array}$ \\
\hline Outside Withdrawal Area & & & \\
Immediately Qutside & & & \\
MAY-01-609 & & 9 & $103-113$ \\
MAY-01-610 & $86-92$ & 9 & $185-200$ \\
MAY-01-640 & $86-92$ & 4 & NA \\
MAY-01-665 & $86-88,92$ & 6 & $260-270$ \\
MAY-01-666 & $90-92,94$ & 5 & $230-240$ \\
MAY-01-667 & $89-92$ & 6 & $80-89$ \\
MAY-01-668 & $89-92,95$ & 5 & $220-229$ \\
MAY-01-669 & $89-92$ & 4 & $330-350$ \\
MAY-01-691 & $90-92$ & 6 & $160-170$ \\
Further 0utside & $87-87-90,92$ & & \\
MAY-01-608 & & & $225-245$ \\
MAY-01-641 & $86-92$ & 9 & NA \\
MAY-01-642 & $86-92$ & 8 & $220-230$ \\
MAY-01-670 & 86 & 1 & $400-420$ \\
MAY-01-674 & 90,92 & 3 & $380-390$ \\
MAY-01-677 & $90-92,95$ & 6 & $254-263$ \\
\hline NA - & $90-92$ & 5 &
\end{tabular}

NA - not available. 
the Maybell site typically have 100 or more observations per constituent. The 0.10 level of significance was applied for each evaluated constituent.

The hypothesis was tested that all background and tailings-area wells access ground water with the same average concentration. Rejection of the hypothesis implies that at least one well in the group differs from the others. In such cases, individual followup tests were conducted comparing the average concentration of each of the nine tailings-area wells to the average background concentration. In order to control the probability of incurring one or more false positive results among the nine tests at approximately 0.10 , individual tests were evaluated at the $0.10 / 9=0.011$ level of significance. The statistical comparison procedures involved 24 constituents in the ground water at the Maybell site. Table 3.2 presents these constituents and indicates which of the nine tailings-area wells have average concentrations statistically above average background.

\subsection{BACKGROUND WATER QUALITY SUMMARY}

Background water quality is defined as the quality of ground water that would be present at the site if uranium milling activities had not taken place. Background monitor wells 601, 602, 660,671, 690,692, 693, and 694 are located sufficiently upgradient or downgradient from the tailings pile to not be affected by tailings leachate. Domestic well 650 was included in previous characterizations of background ground water quality in the Browns Park Formation (DOE, 1994), but was omitted for this assessment because of its distance from the site (more than $5 \mathrm{mi}[8 \mathrm{~km}]$ ).

Background ground water is locally variable and generally poor in the vicinity of the Maybell site. Large amounts of low-to intermediate-grade, sub-economic mineralized material are present in the Browns Park Formation. It is estimated that the Maybell area could contain at least 200 million pounds $(90$ million kilograms [kg]) of uranium oxide in intermediate-grade resources (Chenoweth, 1986). These unmined intermediate-grade deposits are a natural source for uranium and other ore-related constituents, such as arsenic and selenium, in the ground water. In addition, several open pit mines are located hydraulically upgradient of the Maybell site. The Gertrude, Sage, and an unnamed strip mine located just northeast of the Maybell site are open pit mines that represent additional potential sources of contamination for ground water at the Maybell site (Figure 2.1). Portions of the Browns Park Formation have become oxidized through mining activities, resulting in mobilization of arsenic, cadmium, molybdenum, lead, radium, selenium, and uranium, to levels above UMTRA Project maximum concentration levels (MCLs) in some background wells (DOE, 1994). Thus, constituents in ground water may be derived from both natural (mineralized zones) and man-made sources (exploration drilling and open pit mining) independent of the uranium milling activities that took place at the Maybell site. On the basis of widespread ambient contamination in the region from uranium ore deposits, background ground water at the site is classified as limited use ground water (DOE, 1994). 
Table 3.2 Constituents present above background concentrations under or near the tailings pile, Maybell, Colorado, site

\begin{tabular}{|c|c|c|c|c|c|c|c|c|c|}
\hline \multirow[b]{2}{*}{ constituent } & \multicolumn{9}{|c|}{ Well Location } \\
\hline & 606 & 643 & 644 & 646 & 647 & 648 & 649 & 661 & 673 \\
\hline \multicolumn{10}{|l|}{ Inorganic } \\
\hline Aluminum & $x$ & $x$ & & & & $x$ & $x$ & & \\
\hline Ammonium & & & & $x$ & & & & & \\
\hline Cadmium & $x$ & & & & & & & & \\
\hline Calcium & $\mathrm{X}$ & $x$ & $\mathrm{x}$ & $x$ & $x$ & $x$ & $x$ & $x$ & $x$ \\
\hline Chloride & $x$ & & $x$ & $x$ & $x$ & $x$ & $x$ & $x$ & $x$ \\
\hline Copper & & $x$ & $\mathrm{x}$ & & $x$ & $x$ & $x$ & & \\
\hline Fluoride & $x$ & $x$ & $x$ & $x$ & & $x$ & $x$ & & \\
\hline Iron & $x$ & & & & & & & & \\
\hline Magnesium & $x$ & $x$ & $x$ & $x$ & $x$ & $x$ & $x$ & $\mathrm{x}$ & $x$ \\
\hline Manganese & $X$ & $X$ & & $X$ & & & & & \\
\hline Molybdenum & $\mathrm{x}$ & & & $x$ & & $x$ & & & \\
\hline Nitrate & $x$ & $x$ & $x$ & $x$ & $x$ & $x$ & $x$ & $x$ & $x$ \\
\hline Phosphate & & $x$ & $\mathrm{X}$ & $\mathrm{X}$ & $x$ & $x$ & $x$ & & \\
\hline Potassium & $x$ & $\mathrm{X}$ & $x$ & $x$ & $\mathrm{X}$ & $x$ & $x$ & $\mathrm{x}$ & \\
\hline Selenium & $x$ & $\mathrm{x}$ & $x$ & $x$ & $x$ & $x$ & & $x$ & $x$ \\
\hline Sodium & $x$ & $x$ & $x$ & $x$ & & $x$ & $x$ & $x$ & $x$ \\
\hline Strontium & & $\mathrm{x}$ & $x$ & $x$ & $x$ & $x$ & $x$ & $x$ & $x$ \\
\hline Sulfate & $x$ & $x$ & $x$ & $x$ & $x$ & $x$ & $x$ & & $x$ \\
\hline Uranium & $x$ & $x$ & $x$ & $x$ & $x$ & $x$ & $x$ & $x$ & $x$ \\
\hline Zinc & $x$ & $\mathrm{x}$ & & & & & & & \\
\hline \multicolumn{10}{|l|}{ Radionuclides } \\
\hline Lead-210 & $x$ & $x$ & $x$ & & $\mathrm{x}$ & $x$ & $x$ & & \\
\hline Polonium-210 & & $\mathrm{x}$ & & & $x$ & & & & \\
\hline Radium-226 & $x$ & $x$ & $x$ & $\mathrm{x}$ & & $x$ & $x$ & & \\
\hline Thorium-230 & & & & & & $x$ & $x$ & & \\
\hline
\end{tabular}

Note: $\mathrm{X}$ - statistically above average background. 
Because these natural and man-made sources are nonuniformly distributed in the area, background ground water quality is geographically highly variable. In addition, it has been hypothesized that hydrocarbons derived from underlying Cretaceous formations entered the Browns Park Formation along steeply dipping faults and created a reducing environment favorable for the precipitation of uranium (Chenoweth, 1986). Resulting ore bodies are local vein-like and tabular deposits adjacent to faults. Consequently, redox conditions (redox [Eh] representing a major class of chemical reactions, is the tendency for electron transfer reactions to occur) are variable on a scale of a few hundred feet. The wide variation in Eh measurements observed at the site (105 to 573 millivolts [ $\mathrm{mV}]$ ] is accompanied by a similar geographic variability in concentrations of redox sensitive constituents like iron and manganese.

The $\mathrm{pH}$ of these waters tends to be near neutral (6.8 to 7.2) but, again pH is locally variable. For example, the $\mathrm{pH}$ of ground water in monitor well 601 is acidic (near $\mathrm{pH} 5$ ) as a result of localized sulfide oxidation within the ore zones at the site. Total dissolved solids range from 257 to 4940 milligrams per liter $(\mathrm{mg} / \mathrm{L}$ ) in background ground water and alkalinity (as $\mathrm{mg} / \mathrm{L} \mathrm{CaCO}$ ) ranges from 4 to 566 . In general, the background ground water is classified as a calcium bicarbonate/sulfate type (Figure 3.1).

Table 3.3 summarizes the background ground water quality data for monitored constituents at the site. For each background well, the median concentration of a constituent from multiple sampling rounds was computed. The background wells were then ranked from lowest to highest on the basis of their medians. Table 3.3 shows the median concentration of the background well with the lowest ranking, the middle ranking, and the highest ranking. This table arrangement was selected to illustrate the high degree of geographic variation in concentration between background wells.

\subsection{MAGNITUDE OF SITE-RELATED GROUND WATER CONTAMINATION}

Acid leaching, followed by resin-in-pulp ion exchange extraction of uranium ores contributed sulfuric acid and ammonium nitrate to the tailings pile, and, thus, to the ground water at the Maybell site. Additionally, sodium chlorate was used as an oxidant. Therefore, indicators of contamination that might be expected in down gradient wells are the ammonium, nitrate, sulfate, and chloride ions. Contaminants that can be expected in association with the uranium ores themselves include arsenic, molybdenum, selenium, uranium, and vanadium (Evans, 1987).

A map showing the highest observed concentrations of nitrate and uranium concentrations in monitor wells at the site is presented in Figure 3.2. These two constituents are among the most mobile contaminants derived from uranium processing at the site. Therefore, levels of these constituents above ambient background define the maximum extent of processing related contamination. Because background conditions are so variable, the exact edge of the contaminant plume is not well defined. However, Figure 3.2 indicates 
Figure 3.1

Trilinear Plot Showing Major Ion Concentrations

\section{Maybell, Colorado, Site}

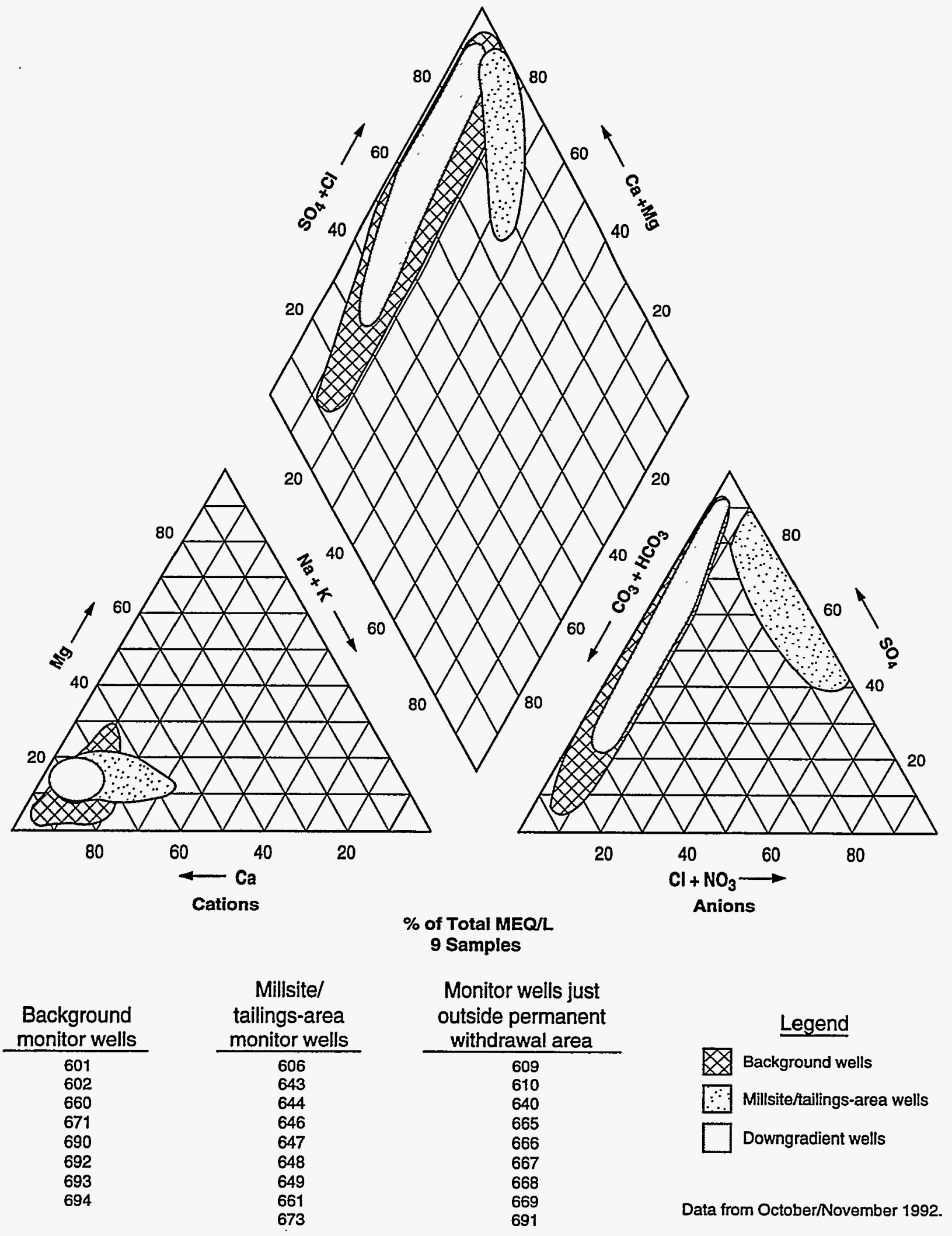

MAC: SITEMAYBELLBLRATTRILINEAR PLOT 
Table 3.3 Ground water quality in the Brown's Park Formation, Maybell, Colorado site

\begin{tabular}{|c|c|c|c|}
\hline \multirow[b]{2}{*}{ Constituent well group } & \multicolumn{3}{|c|}{$\begin{array}{l}\text { Median concentration" } \\
\text { (mg/L) }\end{array}$} \\
\hline & Lowest well & Middle well & Highest well \\
\hline Aluminum & & & \\
\hline $\begin{array}{l}\text { Background } \\
\text { Tailings-area } \\
\text { Adjacent } \\
\text { Outside PWA }\end{array}$ & $\begin{array}{l}<0.05 \\
<0.05 \\
<0.05 \\
<0.05\end{array}$ & $\begin{array}{r}<0.10 \\
0.20 \\
0.08 \\
<0.10\end{array}$ & $\begin{array}{r}0.21 \\
1.57 \\
<0.10 \\
0.20\end{array}$ \\
\hline $\begin{array}{l}\text { Ammonium } \\
\text { Background } \\
\text { Tailings-area } \\
\text { Adjacent } \\
\text { Outside PWA }\end{array}$ & $\begin{array}{l}<0.1 \\
<0.1 \\
<0.1 \\
<0.1\end{array}$ & $\begin{array}{r}0.2 \\
<0.1 \\
<0.1 \\
<0.1\end{array}$ & $\begin{array}{l}0.5 \\
84 \\
<0.1 \\
0.2\end{array}$ \\
\hline $\begin{array}{l}\text { Antimony } \\
\text { Background } \\
\text { Tailings-area } \\
\text { Adjacent } \\
\text { Outside PWA }\end{array}$ & $\begin{array}{l}<0.003 \\
<0.003 \\
<0.003 \\
<0.003\end{array}$ & $\begin{array}{l}<0.003 \\
<0.003 \\
<0.003 \\
<0.003\end{array}$ & $\begin{array}{r}0.004 \\
0.014 \\
<0.003 \\
<0.003\end{array}$ \\
\hline $\begin{array}{l}\text { Arsenic } \\
\qquad \begin{array}{l}\text { Background } \\
\text { Tailings-area } \\
\text { Adjacent } \\
\text { Outside PWA }\end{array}\end{array}$ & $\begin{array}{r}<0.008 \\
0.007 \\
<0.008 \\
<0.010\end{array}$ & $\begin{array}{r}0.01 \\
0.01 \\
<0.01 \\
<0.01\end{array}$ & $\begin{array}{l}0.05 \\
0.20 \\
0.07 \\
0.03\end{array}$ \\
\hline $\begin{array}{l}\text { Barium } \\
\text { Background } \\
\text { Tailings-area } \\
\text { Adjacent } \\
\text { Outside PWA }\end{array}$ & $\begin{array}{l}<0.1 \\
<0.1 \\
<0.1 \\
<0.1\end{array}$ & $\begin{array}{l}<0.1 \\
<0.1 \\
<0.1 \\
<0.1\end{array}$ & $\begin{aligned} & 0.2 \\
< & 0.1 \\
< & 0.1 \\
< & 0.1\end{aligned}$ \\
\hline $\begin{array}{l}\text { Beryllium } \\
\text { Background } \\
\text { Tailings-area } \\
\text { Adjacent } \\
\text { Outside PWA }\end{array}$ & $\begin{array}{l}<0.005 \\
<0.008 \\
<0.005 \\
<0.005\end{array}$ & $\begin{array}{l}<0.005 \\
<0.008 \\
<0.008 \\
<0.008\end{array}$ & $\begin{array}{l}<0.01 \\
<0.01 \\
<0.01 \\
<0.03\end{array}$ \\
\hline $\begin{array}{l}\text { Boron } \\
\text { Background } \\
\text { Tailings-area } \\
\text { Adjacent } \\
\text { Outside PWA }\end{array}$ & $\begin{array}{l}<0.1 \\
<0.1 \\
<0.1 \\
<0.1\end{array}$ & $\begin{array}{l}<0.1 \\
<0.1 \\
<0.1 \\
<0.1\end{array}$ & $\begin{array}{r}0.6 \\
0.1 \\
<0.1 \\
0.2\end{array}$ \\
\hline $\begin{array}{l}\text { Cadmium } \\
\text { Background } \\
\text { Tailings-area } \\
\text { Adjacent } \\
\text { Outside PWA }\end{array}$ & $\begin{array}{l}<0.001 \\
<0.001 \\
<0.001 \\
<0.001\end{array}$ & $\begin{array}{l}<0.001 \\
<0.001 \\
<0.001 \\
<0.001\end{array}$ & $\begin{array}{r}0.002 \\
0.002 \\
<0.001 \\
<0.001\end{array}$ \\
\hline
\end{tabular}


Table 3.3 Ground water quality in the Brown's Park Formation, Maybell, Colorado site (Continued)

\begin{tabular}{|c|c|c|c|}
\hline \multirow[b]{2}{*}{ Constituent well group } & \multicolumn{3}{|c|}{$\begin{array}{l}\text { Median concentration } \\
\text { (mg/L) }\end{array}$} \\
\hline & Lowest well & Middle well & Highest well \\
\hline Calcium & & & \\
\hline $\begin{array}{l}\text { Background } \\
\text { Tailings-area } \\
\text { Adjacent } \\
\text { Outside PWA }\end{array}$ & $\begin{array}{r}63 \\
273 \\
44 \\
68\end{array}$ & $\begin{array}{l}262 \\
728 \\
420 \\
117\end{array}$ & $\begin{array}{r}659 \\
1080 \\
566 \\
414\end{array}$ \\
\hline $\begin{array}{l}\text { Chloride } \\
\qquad \begin{array}{l}\text { Background } \\
\text { Tailings-area } \\
\text { Adjacent } \\
\text { Outside PWA }\end{array}\end{array}$ & $\begin{array}{c}6.1 \\
10 \\
2.8 \\
8.4\end{array}$ & $\begin{array}{l}13 \\
48 \\
13 \\
12\end{array}$ & $\begin{array}{r}32 \\
142 \\
297 \\
13\end{array}$ \\
\hline $\begin{array}{l}\text { Chromium } \\
\text { Background } \\
\text { Tailings-area } \\
\text { Adjacent } \\
\text { Outside PWA }\end{array}$ & $\begin{array}{l}<0.01 \\
<0.01 \\
<0.01 \\
<0.01\end{array}$ & $\begin{array}{l}<0.01 \\
<0.01 \\
<0.01 \\
<0.01\end{array}$ & $\begin{array}{r}<0.01 \\
<0.03 \\
<0.01 \\
0.03\end{array}$ \\
\hline $\begin{array}{l}\text { Cobalt } \\
\text { Background } \\
\text { Tailings-area } \\
\text { Adjacent } \\
\text { Outside PWA }\end{array}$ & $\begin{array}{l}<0.05 \\
<0.04 \\
<0.04 \\
<0.04\end{array}$ & $\begin{array}{l}<0.05 \\
<0.05 \\
<0.05 \\
<0.05\end{array}$ & $\begin{array}{l}<0.05 \\
<0.05 \\
<0.05 \\
<0.05\end{array}$ \\
\hline $\begin{array}{l}\text { Copper } \\
\text { Background } \\
\text { Tailings-area } \\
\text { Adjacent } \\
\text { Outside PWA }\end{array}$ & $\begin{array}{l}<0.02 \\
<0.02 \\
<0.02 \\
<0.02\end{array}$ & $\begin{array}{l}<0.02 \\
<0.02 \\
<0.02 \\
<0.02\end{array}$ & $\begin{array}{r}<0.02 \\
0.04 \\
<0.02 \\
<0.02\end{array}$ \\
\hline $\begin{array}{l}\text { Cyanide } \\
\qquad \begin{array}{l}\text { Background } \\
\text { Tailings-area } \\
\text { Adjacent } \\
\text { Outside PWA }\end{array}\end{array}$ & $\begin{array}{l}<0.01 \\
<0.01 \\
<0.01 \\
<0.01\end{array}$ & $\begin{array}{l}<0.01 \\
<0.01 \\
<0.01 \\
<0.01\end{array}$ & $\begin{array}{l}<0.01 \\
<0.01 \\
<0.01 \\
<0.01\end{array}$ \\
\hline $\begin{array}{l}\text { Fluoride } \\
\qquad \begin{array}{l}\text { Background } \\
\text { Tailings-area } \\
\text { Adjacent } \\
\text { Outside PWA }\end{array}\end{array}$ & $\begin{array}{r}0.1 \\
0.2 \\
0.1 \\
<0.1\end{array}$ & $\begin{array}{l}0.2 \\
0.3 \\
0.2 \\
0.2\end{array}$ & $\begin{array}{l}0.6 \\
0.7 \\
0.4 \\
0.4\end{array}$ \\
\hline $\begin{array}{l}\text { Background } \\
\text { Tailings-area } \\
\text { Adjacent } \\
\text { Outside PWA }\end{array}$ & $\begin{array}{r}0.03 \\
<0.03 \\
<0.03 \\
<0.04\end{array}$ & $\begin{array}{l}0.17 \\
0.11 \\
0.39 \\
0.07\end{array}$ & $\begin{array}{l}2.2 \\
9.1 \\
4.2 \\
0.2\end{array}$ \\
\hline
\end{tabular}


Table 3.3 Ground water quality in the Brown's Park Formation, Maybell, Colorado site (Continued)

\begin{tabular}{|c|c|c|c|}
\hline \multirow[b]{2}{*}{ Constituent well group ${ }^{b}$} & \multicolumn{3}{|c|}{$\begin{array}{l}\text { Median concentration" } \\
\text { (mg/L) }\end{array}$} \\
\hline & Lowest well & Middle well & Highest well \\
\hline Lead & & & \\
\hline $\begin{array}{l}\text { Background } \\
\text { Tailings-area } \\
\text { Adjacent } \\
\text { Outside PWA }\end{array}$ & $\begin{array}{l}<0.005 \\
<0.005 \\
<0.003 \\
<0.008\end{array}$ & $\begin{array}{l}<0.01 \\
<0.01 \\
<0.005 \\
<0.01\end{array}$ & $\begin{array}{l}<0.01 \\
<0.01 \\
<0.01 \\
<0.01\end{array}$ \\
\hline $\begin{array}{l}\text { Magnesium } \\
\text { Background } \\
\text { Tailings-area } \\
\text { Adjacent } \\
\text { Outside PWA }\end{array}$ & $\begin{array}{r}5 \\
19 \\
5 \\
7\end{array}$ & $\begin{array}{l}19 \\
89 \\
34 \\
12\end{array}$ & $\begin{array}{r}93 \\
160 \\
57 \\
41\end{array}$ \\
\hline $\begin{array}{l}\text { Manganese } \\
\text { Background } \\
\text { Tailings-area } \\
\text { Adjacent } \\
\text { Outside PWA }\end{array}$ & $\begin{array}{r}0.05 \\
0.02 \\
<0.01 \\
<0.02\end{array}$ & $\begin{array}{l}0.19 \\
0.18 \\
0.18 \\
0.04\end{array}$ & $\begin{array}{l}5.2 \\
4.2 \\
0.7 \\
0.2\end{array}$ \\
\hline $\begin{array}{l}\text { Mercury } \\
\text { Background } \\
\text { Tailings-area } \\
\text { Adjacent } \\
\text { Outside PWA }\end{array}$ & $\begin{array}{l}<0.0002 \\
<0.0002 \\
<0.0002 \\
<0.0002\end{array}$ & $\begin{array}{l}<0.0002 \\
<0.0002 \\
<0.0002 \\
<0.0002\end{array}$ & $\begin{array}{l}<0.0002 \\
<0.0002 \\
<0.0002 \\
<0.0002\end{array}$ \\
\hline $\begin{array}{l}\text { Molybdenum } \\
\text { Background } \\
\text { Tailings-area } \\
\text { Adjacent } \\
\text { Outside PWA }\end{array}$ & $\begin{array}{l}<0.01 \\
<0.01 \\
<0.01 \\
<0.01\end{array}$ & $\begin{array}{r}<0.02 \\
<0.05 \\
0.02 \\
0.02\end{array}$ & $\begin{array}{l}0.06 \\
0.09 \\
0.09 \\
0.04\end{array}$ \\
\hline $\begin{array}{ll}\text { Nickel } & \\
& \text { Background } \\
\text { Tailings-area } \\
\text { Adjacent } \\
\text { Outside PWA }\end{array}$ & $\begin{array}{l}<0.04 \\
<0.04 \\
<0.04 \\
<0.04\end{array}$ & $\begin{array}{l}<0.04 \\
<0.04 \\
<0.04 \\
<0.04\end{array}$ & $\begin{array}{l}<0.04 \\
<0.05 \\
<0.04 \\
<0.04\end{array}$ \\
\hline $\begin{array}{l}\text { Nitrate } \\
\text { Background } \\
\text { Tailings-area } \\
\text { Adjacent } \\
\text { Outside PWA }\end{array}$ & $\begin{array}{l}<1.0 \\
<1.0 \\
<1.0 \\
<1.0\end{array}$ & $\begin{array}{c}<1.7 \\
950 \\
3.7 \\
2.6\end{array}$ & $\begin{array}{r}9 \\
1650 \\
22 \\
5\end{array}$ \\
\hline $\begin{array}{l}\text { Phosphate } \\
\text { Background } \\
\text { Tailings-area } \\
\text { Adjacent } \\
\text { Outside PWA }\end{array}$ & $\begin{array}{r}\quad 0.1 \\
<0.1 \\
<0.1 \\
<0.1\end{array}$ & $\begin{array}{r}0.5 \\
1.9 \\
<0.1 \\
<0.1\end{array}$ & $\begin{array}{r}1.1 \\
5.0 \\
0.2 \\
<0.5\end{array}$ \\
\hline
\end{tabular}


Table 3.3 Ground water quality in the Brown's Park Formation, Maybell, Colorado site (Continued)

\begin{tabular}{|c|c|c|c|}
\hline \multirow[b]{2}{*}{ Constituent well group } & \multicolumn{3}{|c|}{$\begin{array}{l}\text { Median concentration } \\
\text { (mg/L) }\end{array}$} \\
\hline & Lowest well & Middle well & Highest well \\
\hline $\begin{array}{l}\text { Potassium } \\
\text { Background } \\
\text { Tailings-area } \\
\text { Adjacent } \\
\text { Outside PWA }\end{array}$ & $\begin{array}{l}2.1 \\
5.1 \\
1.7 \\
2.6\end{array}$ & $\begin{array}{c}4.9 \\
16 \\
7.0 \\
4.3\end{array}$ & $\begin{array}{r}28 \\
35 \\
13 \\
5\end{array}$ \\
\hline $\begin{array}{l}\text { Selenium } \\
\text { Background } \\
\text { Tailings-area } \\
\text { Adjacent } \\
\text { Outside PWA }\end{array}$ & $\begin{array}{l}<0.005 \\
<0.005 \\
<0.005 \\
<0.005\end{array}$ & $\begin{array}{c}<0.005 \\
0.79 \\
<0.005 \\
<0.005\end{array}$ & $\begin{array}{c}1.1 \\
1.4 \\
<0.02 \\
0.02\end{array}$ \\
\hline $\begin{array}{ll}\text { Silica } & \\
& \text { Background } \\
& \text { Tailings-area } \\
& \text { Adjacent } \\
& \text { Outside PWA }\end{array}$ & $\begin{array}{l}27 \\
22 \\
23 \\
25\end{array}$ & $\begin{array}{l}48 \\
50 \\
39 \\
40\end{array}$ & $\begin{array}{l}84 \\
57 \\
52 \\
58\end{array}$ \\
\hline $\begin{array}{l}\text { Sodium } \\
\text { Background } \\
\text { Tailings-area } \\
\text { Adjacent } \\
\text { Outside PWA }\end{array}$ & $\begin{array}{l}15 \\
18 \\
7.0 \\
9.5\end{array}$ & $\begin{array}{r}49 \\
153 \\
22 \\
13\end{array}$ & $\begin{array}{r}323 \\
423 \\
33 \\
32\end{array}$ \\
\hline $\begin{array}{ll}\text { Silver } & \\
& \text { Background } \\
& \text { Tailings-area } \\
\text { Adjacent } \\
\text { Outside PWA }\end{array}$ & $\begin{array}{l}<0.01 \\
<0.01 \\
<0.01 \\
<0.01\end{array}$ & $\begin{array}{l}<0.01 \\
<0.015 \\
<0.01 \\
<0.01\end{array}$ & $\begin{array}{r}<0.01 \\
0.02 \\
<0.01 \\
<0.03\end{array}$ \\
\hline $\begin{array}{l}\text { Strontium } \\
\text { Background } \\
\text { Tailings-area } \\
\text { Adjacent } \\
\text { Outside PWA }\end{array}$ & $\begin{array}{l}0.2 \\
0.9 \\
0.2 \\
0.5\end{array}$ & $\begin{array}{l}1.3 \\
2.7 \\
1.0 \\
0.7\end{array}$ & $\begin{array}{l}3.2 \\
3.8 \\
2.9 \\
1.6\end{array}$ \\
\hline $\begin{array}{l}\text { Sulfate } \\
\text { Background } \\
\text { Tailings-area } \\
\text { Adjacent } \\
\text { Outside PWA }\end{array}$ & $\begin{array}{r}16 \\
610 \\
17 \\
44\end{array}$ & $\begin{array}{r}684 \\
1580 \\
785 \\
137\end{array}$ & $\begin{array}{l}2120 \\
1840 \\
1570 \\
1010\end{array}$ \\
\hline $\begin{array}{l}\text { Thallium } \\
\text { Background } \\
\text { Tailings-area } \\
\text { Adjacent } \\
\text { Outside PWA }\end{array}$ & $\begin{array}{l}<0.01 \\
<0.01 \\
<0.01 \\
<0.01\end{array}$ & $\begin{array}{l}<0.01 \\
<0.01 \\
<0.01 \\
<0.01\end{array}$ & $\begin{array}{l}<0.01 \\
<0.03 \\
<0.01 \\
<0.03\end{array}$ \\
\hline
\end{tabular}


Table 3.3 Ground water quality in the Brown's Park Formation, Maybell, Colorado site (Continued)

Median concentration"

(mg/L)

\begin{tabular}{|c|c|c|c|}
\hline \multirow[b]{2}{*}{ Constituent well group } & \multirow{3}{*}{ Lowest well } & \multirow{3}{*}{ Middle well } & \multirow{3}{*}{ Highest well } \\
\hline & & & \\
\hline Tin & & & \\
\hline $\begin{array}{l}\text { Background } \\
\text { Tailings-area } \\
\text { Adjacent } \\
\text { Outside PWA }\end{array}$ & $\begin{array}{l}<0.005 \\
<0.005 \\
<0.005 \\
<0.005\end{array}$ & $\begin{array}{r}<0.005 \\
0.012 \\
<0.005 \\
<0.005\end{array}$ & $\begin{array}{r}0.019 \\
0.030 \\
0.011 \\
<0.005\end{array}$ \\
\hline \multicolumn{4}{|l|}{ Uranium } \\
\hline $\begin{array}{l}\text { Background } \\
\text { Tailings-area } \\
\text { Adjacent } \\
\text { Outside PWA }\end{array}$ & $\begin{array}{r}0.002 \\
<0.003 \\
0.002 \\
<0.003\end{array}$ & $\begin{array}{l}0.004 \\
0.39 \\
0.022 \\
<0.003\end{array}$ & $\begin{array}{l}0.083 \\
7.0 \\
0.10 \\
0.039\end{array}$ \\
\hline \multicolumn{4}{|l|}{ Vanadium } \\
\hline $\begin{array}{l}\text { Background } \\
\text { Tailings-area } \\
\text { Adjacent } \\
\text { Outside PWA }\end{array}$ & $\begin{array}{r}<0.01 \\
<0.01 \\
<0.01 \\
0.01\end{array}$ & $\begin{array}{l}0.02 \\
0.03 \\
0.03 \\
0.02\end{array}$ & $\begin{array}{r}0.03 \\
<0.05 \\
0.04 \\
0.04\end{array}$ \\
\hline
\end{tabular}

Zinc

$\begin{array}{llll}\text { Background } & <0.005 & 0.009 & 0.046 \\ \text { Tailings-area } & <0.005 & 0.026 & 0.14 \\ \text { Adjacent } & <0.005 & 0.008 & 0.014 \\ \text { Outside PWA } & <0.005 & 0.005 & 0.019\end{array}$

Radionuclides

Lead-210

Background

Tailings-area

Adjacent

Outside PWA

Polonium-210

Background

Tailings-area

Adjacent

Outside PWA

Radium-226

Background

Tailings-area

Adjacent

Outside PWA
0.0

0.2

0.6

0.0
0.6

2.3

0.8

0.7

0.2

0.4

0.4

0.2

0.4

0.8

0.2

0.5
2.8

7.4

2.7

37
0.1

0.1

0.0

0.0

0.1

0.0

0.7

1.1

0.7

2.5 
Table 3.3 Ground water quality in the Brown's Park Formation, Maybell, Colorado site (Concluded)

\begin{tabular}{cccc}
\hline & \multicolumn{3}{c}{$\begin{array}{c}\text { Median Concentration" } \\
\text { (mg/L) }\end{array}$} \\
\cline { 3 - 4 } Constituent well group & \multicolumn{3}{c}{ Middle well } \\
\hline Radium-228 & Lowest well & Highest well \\
Background & 0.1 & 0.5 & 1.3 \\
Tailings-area & 0.3 & 0.9 & 1.7 \\
Adjacent & 0.0 & 0.4 & 1.1 \\
Outside PWA & 0.0 & 0.5 & 1.5 \\
Thorium-230 & & & \\
Background & 0.0 & 0.1 & 0.3 \\
Tailings-area & 0.0 & 0.3 & 0.8 \\
Adjacent & 0.0 & 0.1 & 0.8 \\
Outside PWA & 0.0 & 0.2 & 0.6 \\
\hline
\end{tabular}

The median concentration/activity for any well is found by listing the concentration/activity data for the well from lowest to highest. The median is the middle number in the ordered list. Medians from the different wells within the same well group are then ordered from smallest to largest. Reported is the lowest, the middle, and the highest median among wells in the group. August 1986 through April 1995 filtered ground water samples were used.

'Well groups are: Background monitor wells: MAY-01-0601, -0602, -0660, -0671, -0690, -0692, -0693 , and -0694 . Tailings-area monitor wells: MAY-01-0604, -0605, -0606, -0643, -0644, $-0646,-0647,-0648,-0649,-0661$, and -0673 . Note: well 673 included among on-site wells due to high nitrate concentrations. Adjacent monitor wells loutside the tailings areas, but inside the boundary for the permanent withdrawal area): MAY-01-0662, -0663, -0664, -0672, -0675, $-0676,-0695,-0696$. Outside permanent withdrawal area monitor wells (directly outside the boundary of the permanent withdrawal area): MAY-01-0609, -0610, -0665, -0666, -0667. -0668 , and -0691 . 
Figure 3.2

Highest Observed Nitrate and Uranium Concentrations in Monitor Wells Maybell, Colorado, Site

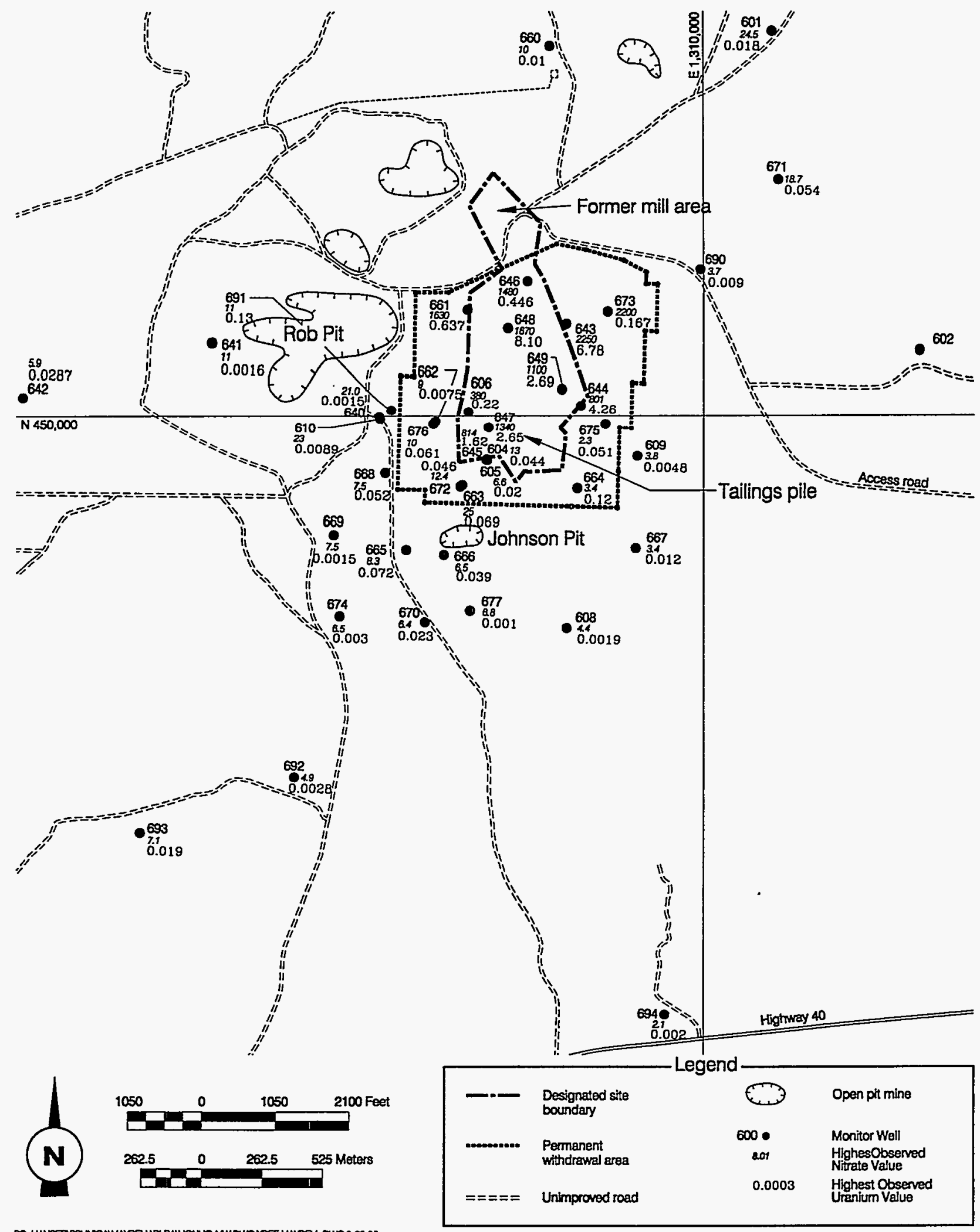

3-14 
that contamination in ground water has not extended more than a few hundred feet from the tailings pile.

Table 3.3 provides for a comparison of background ground water quality to water quality in the tailings area, in areas adjacent to the site and inside the permanent withdrawal area, and immediately outside of the permanent withdrawal area. These data indicate that levels of constituents that were added to groundwater by uranium milling activities (Table 3.2 ) fall off sharply in areas adjacent to the site. All constituents are within the range of background levels in monitor wells that are located outside of the permanent withdrawal area, with the exception of certain radiological constituents, discussed later in this section. The correspondence between the composition of background ground water quality and downgradient water quality is shown graphically in Figure 3.1. Note also that anions contained in contaminated ground water directly beneath the tailings pile plot in a distinctly different field from background and downgradient ground water on this trilinear diagram of major ion species.

Many process and ore related constituents are attenuated in the unsaturated zone between the bottom of the tailings pile and the water table. Water levels measured in the vicinity of the site indicate that the unsaturated zone is from 35 to over $300 \mathrm{ft}(11$ to $90 \mathrm{~m})$ thick. Chemical reaction with plentiful calcite in the tailings subsoil neutralize acidic tailings leachate and precipitate gypsum, removing sulfate from the infiltrating water (DOE, 1994). High concentrations of ferrous iron are stable in acidic tailings leachate (up to $560 \mathrm{mg} / \mathrm{L}$ ) but ferric iron oxyhydroxides are the stable iron species in more neutral environments (Brookins, 1988). Thus, abundant iron oxyhydroxides were precipitated in the tailings sub-soil during neutralization of tailings leachate (DOE, 1994). Iron oxyhydroxides have a strong affinity for many contaminant species and the precipitation of these iron-rich phases enhance the adsorption of arsenic, molybdenum, selenium, uranium, and other contaminant species present in contaminated pore water, mitigating concentrations of these species in ground water beneath the site.

Notwithstanding these attenuation processes, several site contaminants have traveled through the unsaturated zone and are present in ground water directly beneath the tailings pile at the site. Several mechanisms may be responsible for the lack of ground water contamination more than a short distance downgradient of the tailings pile. The process of gypsum and iron oxyhydroxide precipitation may continue in ground water beneath the site, causing some attenuation of trace metals downgradient of the tailings pile (DOE, 1994). In addition, some nitrate may be removed by biologically mediated denitrification processes as suggested by microbiological studies conducted at the site (Thompson and Associates, 1990). It is unlikely, however, that these mechanisms completely remove all contamination downgradient of the site. Other possible mechanisms include: no ground water contamination (the apparent contamination is due to leaky wells drilled through the tailings); or, very slow ground water movement llocal flow conditions in the Browns Park 
Formation are variable or the estimated average ground water velocity of $60 \mathrm{ft}$ per year is an overestimate). Regardless of the reason, ground water contamination has not moved beyond the immediate vicinity of the mill site and tailings pile in the almost $\mathbf{4 0}$ year period since the milling operations began.

Concentrations of radionuclides lead-210 and radium-226 are above ambient background levels in a few monitor wells located outside the permanent withdrawal area, most notably in monitor well 668. However, the elevated levels are not the result of processing-related contamination. Lead-210 and radium-226 are both extremely insoluble in ground water and their movement is strongly retarded relative to more mobile constituents such as nitrate or uranium. Yet, for monitor well 668 , concentrations of both nitrate and uranium fall within the range of background in ground water whereas radium-226 activity measured in ground water from the well is an order of magnitude higher than radium-226 activity measured in ground water directly beneath the tailings pile.

Redox conditions in ground water in monitor well 668 are reducing (Eh commonly in the -65 to $0 \mathrm{mV}$ range), probably as the result of ore forming conditions present nearby. Uranium concentrations are low in this ground water (commonly in the range of 0.002 to $0.004 \mathrm{mg} / \mathrm{L}$ ) because, under reducing conditions, any uranium in ground water would be precipitated as uraninite. Thus, uranium is being concentrated in the aquifer matrix and the local area around monitor well 668 is likely one of the many zones of intermediate grade mineralization in the Maybell area. Lead-210 and radium-226 are daughter products of the uranium decay series. An atom of uranium is stable in the crystalline structure of uraninite but when an atom of uranium decays to another element, the resulting atom may be unstable in the structure and will have a tendency to be released to ground water. Consequently, high levels of lead-210 and radium-226 in these downgradient monitor wells are not indicators of processing related contamination; but, instead, these constituents are signs of uranium ore formation. This process also applies to other members of the uranium decay chain.

To summarize the results of geochemical analysis presented in this section; uranium processing related constituents have not migrated more than a few hundred feet from the tailings pile and there is no evidence that ground water outside the permanent withdrawal area has been contaminated by former uranium processing activities at the Maybell site. High levels of radionuclides in a few off-site wells are the result of ore forming processes.

\subsection{SURFACE WATER}

Surface water near the Maybell site is limited to ponded water in Rob Pit, two seeps in Johnson Wash, and locations along the intermittently flowing Lay Creek. Figure 2.5 shows sampling locations and Table 3.4 indicates the years each location was sampled and the number of rounds of data available from each location. An unnamed pit northeast of Sugarloaf Basin (hereafter referred to as the Sugarloaf Basin pit) and an intermittent stream draining Sugarloaf 
Table 3.4 Years sampled and number of data rounds available for surface sampling locations, Maybell, Colorado, site.

\begin{tabular}{llcc}
\hline & \multicolumn{1}{c}{ Location } & Years sampled & $\begin{array}{c}\text { Number of } \\
\text { rounds }\end{array}$ \\
\hline MAY-01-701 & Johnson Wash & $86,94-95$ & 4 \\
MAY-01-703 & Rob Pit & $86-88$ & 3 \\
MAY-01-704 & Sugarloaf Basin pit & $86-88$ & 4 \\
MAY-01-705 & Lay Creek at confluence with Johnson & $86-88,94-95$ & 8 \\
& Wash & & \\
MAY-01-706 & Lay Creek upstream of Johnson Wash & $86-88,94-95$ & 8 \\
MAY-01-707 & Lay Creek downstream of Johnson Wash & $86-88,94-95$ & 8 \\
MAY-01-718 & Rob Pit & $89-91,94-95$ & 6 \\
MAY-01-719 & Johnson Wash & $89-90,94$ & 3 \\
MAY-01-721 & Wash draining Sugarloaf Basin & $94-95$ & 2 \\
\hline
\end{tabular}


Basin have been sampled as background locations for Rob Pit and Johnson Wash respectively (Figure 2.1 ).

Table $\mathbf{3 . 5}$ summarizes the results of analyses of surface water samples in Johnson Wash and Lay Creek for several constituents that are indicators of contamination. Section 2.6 concludes that because of the distance of the seeps in Johnson Wash and the sampling locations along Lay Creek from the tailings pile and the direction of ground water flow across the site, it is not likely that contamination in ground water beneath the tailings pile could reach the surface through these seeps. A Bureau of Land Management (BLM) well (656) adjacent to Johnson Wash surface seep location 701 was sampled to test whether contamination in seep 701 is derived from ground water or surface sources. Results demonstrate that contamination is related to surface sources. For example, uranium values of $<0.001 \mathrm{mg} / \mathrm{L}$ in well 656 are considerably lower than those found in the surface seep $(0.124 \mathrm{mg} / \mathrm{L})$ less than $100 \mathrm{ft}(30 \mathrm{~m})$ away.

Surface water samples from seeps in Johnson Wash have concentrations of uranium ore related constituents as a result of accidental and routine discharge of tailings material into the wash during the period of mill operation.

Additionally, surface water runoff encountering material released from the tailings pile, as well as material derived from mineralization in the Johnson Wash drainage area contribute to the concentrations of ore related constituents. Sources of constituents in Johnson Wash could include dissolution of nearsurface mineralization, surface runoff from mines, overburden piles, and ore stockpiles, and accumulations of materials in alluvial stream sediments. Because contaminated ground water is not the source of these constituents the surface contamination is addressed under the UMTRA Surface Project.

Levels of uranium ore related constituents in surface water samples from Lay Creek could also be attributed to release of contaminated material from the millsite, as well as material derived from mineralization in both the Johnson Wash and Lay Creek drainage areas. The mineralized trend in the region is present north and east of the millsite, and also south of US Highway 40, thus providing a possible upstream source of uranium where Lay Creek crosses the trend just upstream of the confluence with Johnson Wash. Concentrations of constituents in surface water samples from Lay Creek are dependent on the amount of stream flow and vary according to the time of year sampled. During periods of low flow, evaporation of standing water in ponds would tend to yield higher concentrations than when the water is actively flowing. This is indicated by results of the June 1995 sampling (a period when Lay Creek was actively flowing) from locations 705 and 707 when concentrations of uranium were 0.009 and $0.011 \mathrm{mg} / \mathrm{L}$ respectively. In contrast, uranium values observed in results from the July 1994 sampling (Lay Creek was not flowing) were 0.103 and $0.271 \mathrm{mg} / \mathrm{L}$ for locations 705 and 707 , respectively.

As discussed in Section 2.6, it is possible that contaminants in ground water beneath the tailings pile could reach Rob Pit. However, concentrations of 
Table 3.5 Results of analyses of surface water samples in Johnson Wash and Lay Creek for nitrate, sulfate, and uranium, Maybell, Colorado, site

\begin{tabular}{|c|c|c|c|c|c|}
\hline & $\begin{array}{c}\text { Location } \\
\text { description }\end{array}$ & $\begin{array}{l}\text { Frequency } \\
\text { of detection }\end{array}$ & Minimum & Mean & Maximum \\
\hline Nitrate & \multicolumn{4}{|c|}{ Nitrate } & \\
\hline $\begin{array}{l}\text { MAY-01-721 } \\
\text { Down Stream }\end{array}$ & Sugarloaf Drainage & $0 / 2$ & $<1.0$ & - & $<1.0$ \\
\hline MAY-01-701 & Johnson Wash & $0 / 4$ & $<1.0$ & $<1.0$ & $<1.0$ \\
\hline $\begin{array}{l}\text { MAY-01-719 } \\
\text { Background }\end{array}$ & Johnson Wash & $0 / 2$ & $<1.0$ & - & $<1.0$ \\
\hline MAY-01-706 & Lay Creek & $0 / 7$ & $<1.0$ & $<1.0$ & $<1.0$ \\
\hline MAY-01-705 & Lay Creek & $0 / 7$ & $<1.0$ & $<1.0$ & $<1.0$ \\
\hline MAY-01-707 & Lay Creek & $0 / 5$ & $<1.0$ & $<1.0$ & $<1.0$ \\
\hline \multicolumn{6}{|l|}{ Sulfate } \\
\hline $\begin{array}{l}\text { MAY-01-721 } \\
\text { Down Stream }\end{array}$ & Sugarloaf Drainage & $1 / 1$ & - & 1320 & - \\
\hline MAY-01-701 & Johnson Wash & $3 / 3$ & 1000 & 1050 & 1110 \\
\hline $\begin{array}{l}\text { MAY-01-719 } \\
\text { Background }\end{array}$ & Johnson Wash & $2 / 2$ & 1100 & - & 1150 \\
\hline $\begin{array}{l}\text { MAY-01-706 } \\
\text { Down Stream }\end{array}$ & Lay Creek & $7 / 7$ & 972 & 1308 & 1550 \\
\hline MAY-01-705 & Lay Creek & $7 / 7$ & 98.5 & 1426 & 1880 \\
\hline MAY-01-707 & Lay Creek & $7 / 7$ & 985 & 1473 & 1910 \\
\hline \multicolumn{6}{|l|}{ Uranium } \\
\hline $\begin{array}{l}\text { Background } \\
\text { MAY-01-721 }\end{array}$ & Sugarloaf Drainage & 212 & 0003 & & 000 \\
\hline Down Stream & Sugantuar Liantage & $2 i 2$ & 0.003 & - & 0.029 \\
\hline MAY-01-701 & Johnson Wash & $4 / 4$ & 0.050 & 0.138 & 0.271 \\
\hline $\begin{array}{l}\text { MAY-01-719 } \\
\text { Background }\end{array}$ & Johnson Wash & $3 / 3$ & 0.086 & 0.141 & 0.206 \\
\hline $\begin{array}{l}\text { MAY-01-706 } \\
\text { Down Stream }\end{array}$ & Lay Creek & $8 / 8$ & 0.003 & 0.006 & 0.010 \\
\hline MAY-01-705 & Lay Creok & $8 / 8$ & 0.005 & 0.023 & 0.103 \\
\hline MAY-01-707 & Lay Creek & $8 / 8$ & 0.004 & 0.072 & 0.271 \\
\hline
\end{tabular}

Note: Units are measured as milligrams per liter (mg/L). 
constituents associated with uranium mineralization in the Rob Pit surface water samples are expected because the water is in contact with naturally occurring intermediate-grade mineralization adjacent to and beneath the pit. Similar elevated concentrations of uranium in water samples from the pit near Sugarloaf Basin have also been observed. This pit is located upgradient from the Maybell site and represents background conditions. Water in Rob Pit represents an expression of ground water (water table). However, in the semiarid climate of western Colorado, all bodies of standing water are subject to strong evaporation effects. Consequently, concentrations of constituents that enter these features have could build up over time in both surface water and sediments.

A comparison between the background pit and Rob Pit water quality is presented in Table 3.6. The Sugarloaf Basin pit contains equal or higher concentrations of all constituents except calcium, fluoride, sulfate, and radium226. The Sugarloaf Basin pit is clearly unimpacted by UMTRA processing related contamination, and yet, key indicator parameters associated with uranium ores are much higher in the Sugarloaf Basin pit than in Rob Pit. Uranium, for example, averages an order of magnitude higher in the Sugarloaf Basin pit than in Rob Pit $(3.0 \mathrm{mg} / \mathrm{L}$ compared to $0.38 \mathrm{mg} / \mathrm{L}$ in Rob Pit). This demonstrates that there are not enough background locations to capture the true variability of ground water and surface water conditions at the site. Concentrations of constituents that are higher in Rob Pit than in the Sugarloaf Basin pit are consistent with the range of concentrations of those same constituents found in background ground water. Lower concentrations of uranium and higher concentrations of radium-226 in Rob Pit most likely indicate the nearby presence of current ore forming conditions. Thus, there is no geochemical evidence that Rob Pit has been contaminated by past UMTRA related uranium milling processes. 
Table 3.6 Comparison of water quality in the unnamed background pit to Rob Pit, Maybell, Colorado site

\begin{tabular}{|c|c|c|c|c|}
\hline Constituent & Location & $\begin{array}{l}\text { Number of } \\
\text { samples }\end{array}$ & Median & $\begin{array}{c}\text { Maximum } \\
\text { detected }\end{array}$ \\
\hline $\begin{array}{l}\text { Inorganics } \\
\text { Aluminum }\end{array}$ & $\begin{array}{l}\text { Background } \\
\text { Rob Pit }\end{array}$ & $\begin{array}{l}4 \\
6\end{array}$ & $\begin{array}{r}0.29 \\
<0.13\end{array}$ & $\begin{array}{l}0.30 \\
0.28\end{array}$ \\
\hline Ammonium & $\begin{array}{l}\text { Background } \\
\text { Rob Pit }\end{array}$ & $\begin{array}{l}4 \\
7\end{array}$ & $\begin{array}{l}<0.10 \\
<0.10\end{array}$ & $\begin{array}{l}0.30 \\
0.10\end{array}$ \\
\hline Cadmium & $\begin{array}{l}\text { Background } \\
\text { Rob Pit }\end{array}$ & $\begin{array}{l}4 \\
9\end{array}$ & $\begin{array}{l}<0.003 \\
<0.001\end{array}$ & $\begin{array}{l}0.011 \\
0.001\end{array}$ \\
\hline Calcium & $\begin{array}{l}\text { Background } \\
\text { Rob Pit }\end{array}$ & $\begin{array}{l}4 \\
9\end{array}$ & $\begin{array}{l}311 \\
581\end{array}$ & $\begin{array}{l}351 \\
770\end{array}$ \\
\hline Chloride & $\begin{array}{l}\text { Background } \\
\text { Rob Pit }\end{array}$ & $\begin{array}{l}4 \\
8\end{array}$ & $\begin{array}{l}52 \\
25\end{array}$ & $\begin{array}{l}58 \\
30\end{array}$ \\
\hline Copper & $\begin{array}{l}\text { Background } \\
\text { Rob Pit }\end{array}$ & $\begin{array}{l}4 \\
6\end{array}$ & $\begin{array}{r}0.03 \\
<0.02\end{array}$ & $\begin{array}{l}0.03 \\
0.03\end{array}$ \\
\hline Fluoride & $\begin{array}{l}\text { Background } \\
\text { Rob Pit }\end{array}$ & $\begin{array}{l}4 \\
6\end{array}$ & $\begin{array}{l}0.15 \\
0.79\end{array}$ & $\begin{array}{l}0.18 \\
1.0\end{array}$ \\
\hline Iron & $\begin{array}{l}\text { Background } \\
\text { Rob Pit }\end{array}$ & $\begin{array}{l}4 \\
8\end{array}$ & $\begin{array}{r}0.08 \\
<0.06\end{array}$ & $\begin{array}{l}0.10 \\
0.12\end{array}$ \\
\hline Magnesium & $\begin{array}{l}\text { Background } \\
\text { Rob Pit }\end{array}$ & $\begin{array}{l}4 \\
9\end{array}$ & $\begin{array}{l}74 \\
67\end{array}$ & $\begin{array}{l}93 \\
87\end{array}$ \\
\hline Manganese & $\begin{array}{l}\text { Background } \\
\text { Rob Pit }\end{array}$ & $\begin{array}{l}4 \\
9\end{array}$ & $\begin{array}{l}0.13 \\
0.04\end{array}$ & $\begin{array}{l}0.46 \\
0.64\end{array}$ \\
\hline Molybdenum & $\begin{array}{l}\text { Background } \\
\text { Rob Pit }\end{array}$ & $\begin{array}{l}4 \\
9\end{array}$ & $\begin{array}{r}0.13 \\
<0.01\end{array}$ & $\begin{array}{l}0.19 \\
0.14\end{array}$ \\
\hline Nitrate & $\begin{array}{l}\text { Background } \\
\text { Rob Pit }\end{array}$ & $\begin{array}{c}4 \\
10\end{array}$ & $\begin{array}{r}3.6 \\
<1.0\end{array}$ & $\begin{array}{l}6.6 \\
8.0\end{array}$ \\
\hline Phosphate & $\begin{array}{l}\text { Background } \\
\text { Rob Pit }\end{array}$ & $\begin{array}{c}4 \\
10\end{array}$ & $\begin{array}{l}<0.2 \\
<0.1\end{array}$ & $\begin{array}{l}2.8 \\
0.3\end{array}$ \\
\hline Potassium & $\begin{array}{l}\text { Background } \\
\text { Rob Pit }\end{array}$ & $\begin{array}{l}4 \\
8\end{array}$ & $\begin{array}{l}12 \\
14\end{array}$ & $\begin{array}{l}16 \\
19\end{array}$ \\
\hline Selenium & $\begin{array}{l}\text { Background } \\
\text { Rob Pit }\end{array}$ & $\begin{array}{l}4 \\
9\end{array}$ & $\begin{array}{r}0.011 \\
<0.005\end{array}$ & $\begin{array}{l}0.013 \\
0.036\end{array}$ \\
\hline Sodium & $\begin{array}{l}\text { Background } \\
\text { Rob Pit } \\
\end{array}$ & $\begin{array}{l}4 \\
8 \\
\end{array}$ & $\begin{array}{l}71 \\
39 \\
\end{array}$ & $\begin{array}{l}200 \\
135 \\
\end{array}$ \\
\hline
\end{tabular}


Table 3.6 Comparison of water quality in the unnamed background pit to Rob Pit, Maybell, Colorado site (Concluded)

\begin{tabular}{|c|c|c|c|c|}
\hline Constituent & Location & $\begin{array}{c}\text { Number of } \\
\text { samples }\end{array}$ & Median & $\begin{array}{r}\text { Maximum } \\
\text { detected }\end{array}$ \\
\hline Strontium & $\begin{array}{l}\text { Background } \\
\text { Rob Pit }\end{array}$ & $\begin{array}{l}4 \\
6\end{array}$ & $\begin{array}{l}2.7 \\
2.4\end{array}$ & $\begin{array}{l}3.1 \\
3.1\end{array}$ \\
\hline Sulfate & $\begin{array}{l}\text { Background } \\
\text { Rob Pit }\end{array}$ & $\begin{array}{l}4 \\
8\end{array}$ & $\begin{array}{l}1115 \\
1825\end{array}$ & $\begin{array}{l}1250 \\
2110\end{array}$ \\
\hline Uranium & $\begin{array}{l}\text { Background } \\
\text { Rob Pit }\end{array}$ & $\begin{array}{l}4 \\
8\end{array}$ & $\begin{array}{l}3.0 \\
0.38\end{array}$ & $\begin{array}{l}3.5 \\
0.67\end{array}$ \\
\hline Zinc & $\begin{array}{l}\text { Background } \\
\text { Rob Pit }\end{array}$ & $\begin{array}{l}4 \\
6\end{array}$ & $\begin{array}{r}0.020 \\
<0.007\end{array}$ & $\begin{array}{l}0.033 \\
0.010\end{array}$ \\
\hline \multicolumn{5}{|c|}{ Radionuclides (pCi/L) } \\
\hline Lead-210 & $\begin{array}{l}\text { Background } \\
\text { Rob Pit }\end{array}$ & $\begin{array}{l}4 \\
6\end{array}$ & $\begin{array}{l}5.0 \\
1.0\end{array}$ & $\begin{array}{l}10 \\
17\end{array}$ \\
\hline Polonium-210 & $\begin{array}{l}\text { Background } \\
\text { Rob Pit }\end{array}$ & $\begin{array}{l}4 \\
6\end{array}$ & $\begin{array}{l}5.1 \\
1.2\end{array}$ & $\begin{array}{l}9.4 \\
2.7\end{array}$ \\
\hline Radium-226 & $\begin{array}{l}\text { Background } \\
\text { Rob Pit }\end{array}$ & $\begin{array}{l}4 \\
7\end{array}$ & $\begin{array}{l}0.2 \\
2.2\end{array}$ & $\begin{array}{l}0.7 \\
3.2\end{array}$ \\
\hline Thorium-230 & $\begin{array}{l}\text { Background } \\
\text { Rob Pit }\end{array}$ & $\begin{array}{l}4 \\
6\end{array}$ & $\begin{array}{l}0.7 \\
0.3\end{array}$ & $\begin{array}{l}3.3 \\
17\end{array}$ \\
\hline
\end{tabular}

${ }^{a}$ Filtered surface water quality from August 1986 through April 1995 was used for this evaluation.

Note: Units are measured in milligrams per liter (mg/L) unless otherwise noted.

$\mathrm{pCi} / \mathrm{L}$ - picocurie per liter. 


\subsection{CONCEPTUAL SITE MODEL OF EXPOSURE}

This section discusses the conceptual site model of potential exposure to people and the ecological environment from contaminants in the ground water at the Maybell site.

A complete exposure pathway can occur only if there are a source of contamination, a mechanism of chemical release, a transport medium, an exposure point, and an exposure route. At the Maybell site, because of leaching (mechanism of chemical release) of the tailings pile (source), ground water is contaminated beneath the site with inorganic chemicals and radionuclides. Therefore, ground water is identified as the transport medium for contaminants at this site. An exposure point is defined as the location of potential contact between receptor (e.g., people or livestock) and contaminant (e.g., a well placed in the contaminated ground water). If no exposure points can be identified then, an exposure route (e.g. ingestion of ground water as drinking water) to a receptor cannot be completed.

The conceptual site model of potential exposure for the Maybell site is presented in Figure 4.1. This model is based on the following discussion of current and future land-and water-use patterns and the evaluation of the geochemical and hydrogeological conditions of the contaminated ground water at the Maybell site.

\subsection{CONTAMINANT TRANSPORT SCENARIOS}

As discussed in Sections 2.0 and 3.0, several mechanisms (for example, adsorption, denitrification, precipitation, neutralization processes, and a slow ground water velocity) may be responsible for the absence of site-related contamination beyond a few hundred feet of the tailings pile in the almost 40 year period since milling operations began. Regardless of the reason, ground water is not currently a medium of transport for contaminants beyond the permanent withdrawal area. If ground water geochemical and hydrogeological conditions do not change in the future, ground water will continue not to be a medium of transport for contaminants outside of the permanent withdrawal area. However, current ground water conditions at the Maybell site have the potential to change in the near future because of surface remedial actions.

\subsubsection{Potential impacts of surface remediation on ground water}

Construction activities for surface remediation at the Maybell site began in the spring of 1995 and are scheduled to be completed during 1996. Massive amounts of shaking, compression, and excavation can reasonably be assumed to disturb the equilibrium of pre-remedial ground water conditions. A certain amount of contaminated water, termed transient drainage, will enter the Browns Park Formation beneath the disposal cell during and after construction. The sources of this water are the unsaturated zone, tailings pore fluid, precipitation during construction, and construction water added for compaction or dust control. 
Figure 4.1

Conceptual Site Model of Exposure

Maybell, Colorado, Site

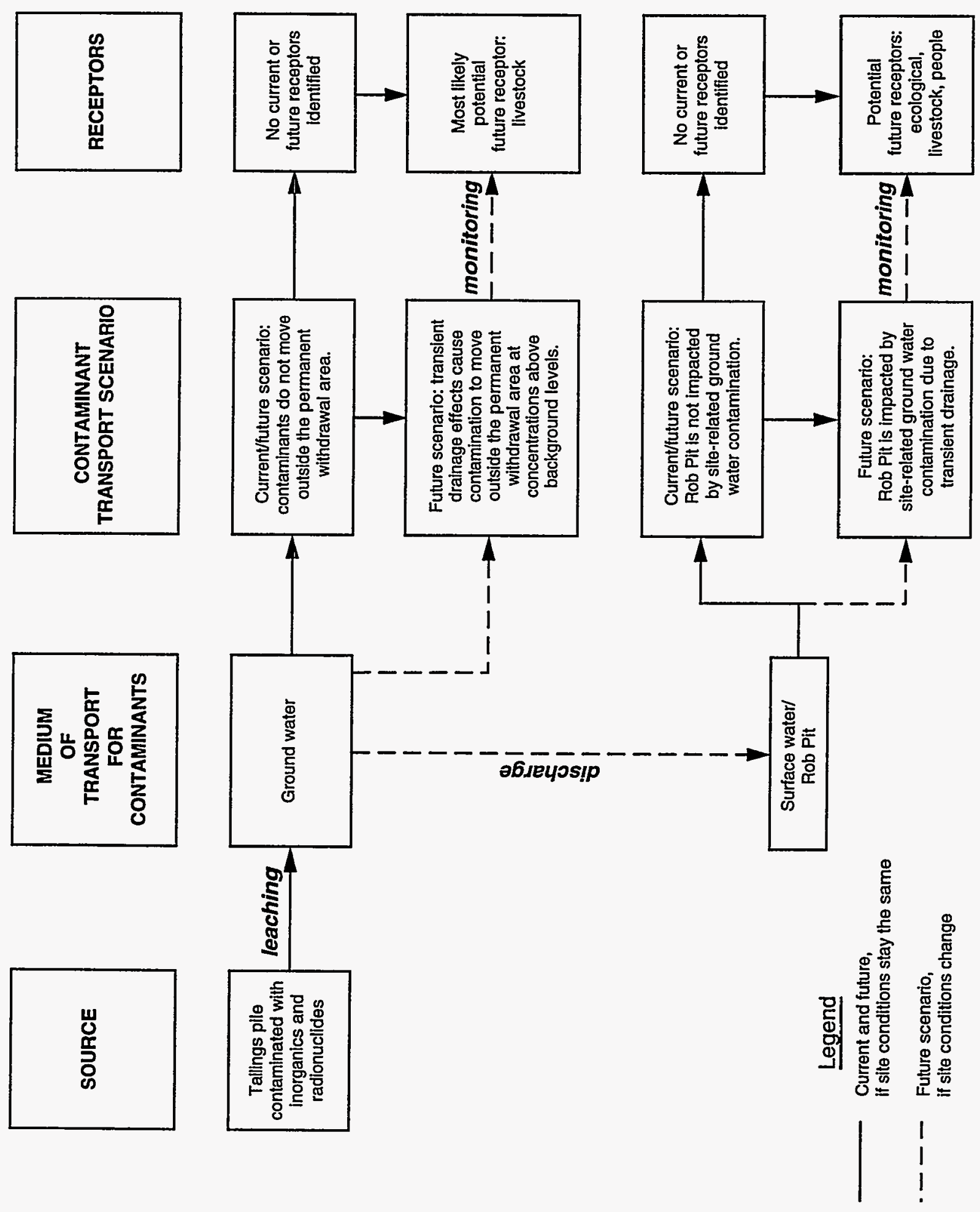

MAC: STTEMAY/BLPACONCEPTL 
The additional water may temporarily alter the level of the ground water beneath the site, thereby, altering the hydraulic gradient of the ground water. The result of this is that contaminated ground water could move outside of the permanent withdrawal area and could increase contaminant concentrations in the aquifer. Currently, the magnitude of these changes has not been estimated. However, modeling efforts are underway. The effect of the transient drainage is important for the Maybell site risk assessment because these ground water impacts could cause the contamination inside the permanent withdrawal area to migrate offsite beyond the permanent withdrawal area at concentrations above those occurring in background areas.

\subsection{GROUND WATER AND LAND USE}

The Maybell site is in a remote location. Historically (and currently) the primary land-use in the area has been ranching, as well as, some recreational use (e.g., hunting and motorcycling). The land surrounding the site is owned by a few local ranchers, the BLM, and the state of Colorado (Figure 4.2). The BLM owns the northern portion of the land where the site is located. The southern portion is privately owned. The DOE has acquired all of the land within the boundary of the permanent withdrawal area and access to the public is restricted. No private ground water wells are or will be permitted within this area. After the surface remediation is complete, adjacent lands which are in temporary withdrawal (as part of the remedial action) will return to normal use. That is, grazing, recreational and agricultural uses will be permitted outside the boundary of the permanent withdrawal area. No agricultural activities requiring the irrigation of crops have been observed in the vicinity of the site. Because the area is used mainly for grazing and the water quality is naturally poor (i.e.., background water quality is classified as a limited use ground water), crop propagation activities are not expected to occur near the Maybell site in the future.

Water use near the Maybell site was identified in a 1990 water use field survey by inspecting well records at the Colorado Division of Water Resources. No residential, industrial/commercial, municipal, or agricultural wells were identified within a $3 \mathrm{mi}(5 \mathrm{~km})$ radius of the site. The results of the first survey were verified by another site visit in October of 1994 (TAC, 1995b). Additionally, it was determined that no new wells had been constructed within the same $3 \mathrm{mi}$ $(5 \mathrm{~km})$ radius of the site since 1990 . Because of the naturally poor water quality in the immediate vicinity of the Maybell site, people live where palatable water can be found. Several domestic wells are located in and near the town of Maybell, $5 \mathrm{mi}(8 \mathrm{~km})$ southwest of the tailings pile. These wells are located in the Yampa River Valley alluvium, with the exception of monitor well 650, which is located in the Browns Park Formation aquifer. Ground water from the Browns Park Formation has been used for limited livestock watering, as two windmilloperated wells formerly existed for this purpose. One windmill-operated well (monitor well 656) was located along Johnson Wash, approximately $1 \mathrm{mi}$ (1.6 $\mathrm{km}$ ) south of the tailings pile, but was removed between 1990 and 1992 (TAC, $1990 ; 1992$ ). The second windmill-operated well (monitor well 631) was 
Figure 4.2

Approximate Land Ownership Boundaries for Areas Surrounding the Maybell, Colorado, Site

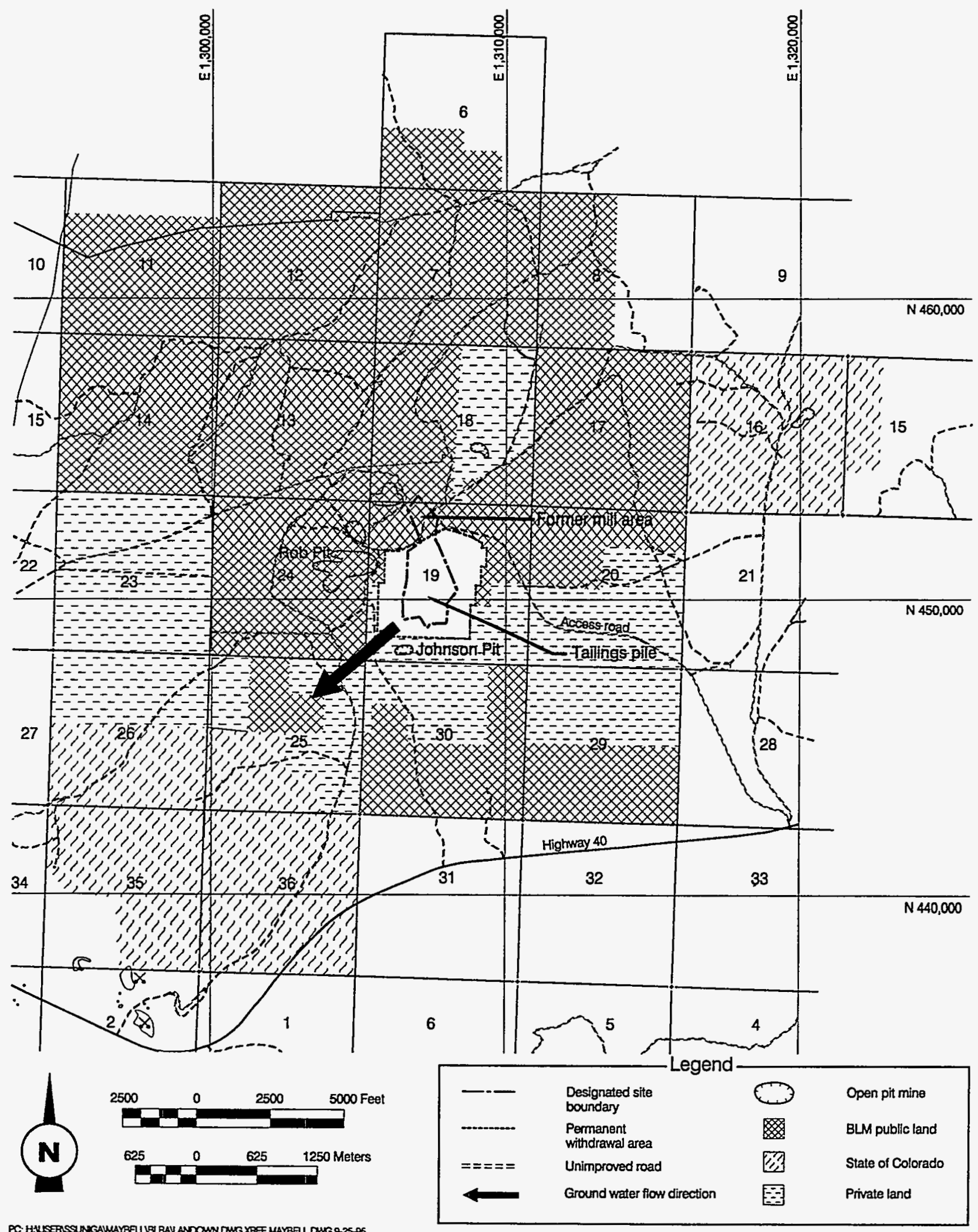


located approximately $2 \mathrm{mi}(3 \mathrm{~km})$ northeast of the tailings pile. Discussions with the well owner indicated that the owner had not used this windmill since 1982 (DOE, 1994). Additionally, the surface water in Rob Pit is currently used by a local rancher to water livestock.

Ground water movement at the site is to the southwest. If the plume were to migrate beyond the permanent withdrawal area, the plume would reach BLM and/or private land (Figure 4.2). People are not allowed to live on BLM land and therefore a well constructed for domestic uses should not occur at any time. However, a permit to construct a well for other uses, for example, livestock watering is allowed on BLM land. Likewise, since it is unlikely that the privately owned land in the vicinity of the site will be used for any purposes other than ranching, it is unlikely that any private wells would be constructed on this land for uses other than livestock watering sources. Additionally, based on current and past land-use of the area, the population growth of the area surrounding the Maybell site is low and this is not expected to change in the future.

To summarize, no complete exposure pathways have been identified for current use of contaminated ground water near the Maybell site because ground water has not transported contaminants above background levels beyond the permanent withdrawal area and, no exposure points have been identified, that is, no wells or discharges of ground water to the surface have been identified where a receptor could come into contact with contaminated ground water. Furthermore, if current hydrogeologic and geochemical conditions do not change in the future, the potential for exposure pathways to exist is not likely because of these same reasons. However, the effect of transient drainage has the potential to change current site conditions and allow ground water under the site to migrate beyond the permanent withdrawal area in concentrations that exceed background levels. If this occurs, then there is a potential for an exposure pathway to be completed. The most likely receptor for the future exposure scenario would be livestock.

\subsection{SURFACE WATER}

As discussed in Sections 2.6 and 3.4, although there is a potential for contaminated ground water from the site to discharge into Rob Pit, surface water quality data indicate that the surface water has not been contaminated by UMTRA related processing activities. Contaminant concentrations are either below or within the range of background concentrations. Therefore, no exposure pathways associated with contaminated surface water or sediment have been identified as complete for current site conditions (Figure 4.2).

However, if transient drainage causes site conditions to change in the future, the potential exists for contaminated ground water to discharge into Rob Pit at levels above background. If this were to occur, then several human health and ecological exposure pathways could be completed. Even though no fish are found in Rob Pit, other aquatic life, benthic organisms, plants, and wildlife live in or have access to the pit. Additionally, a local rancher uses the water in the pit 
as a watering source for livestock. People could also be receptors at this pit. Since recreational activities occur in the area, people could swim in and be exposed by dermal contact with and accidental ingestion of surface water and sediment.

\subsection{CONCLUSIONS}

Contaminants are not being detected above background concentrations outside of the permanent withdrawal area. Because of the geochemical and hydrogeological conditions of the ground water and the lack of exposure points and receptors, no complete exposure pathways have been identified for current ground water use. Furthermore, based on current ground water conditions, and current and projected future land-and water-use patterns of the area, the potential for a complete exposure pathway to exist in the future is unlikely.

However, if current ground water conditions at the site changes in the future because of transient drainage, and the plume migrates beyond the permanent withdrawal area at levels which exceed background concentrations, there is a potential for an exposure pathway to be complete. In this scenario, the ground water would be the medium of transport beyond the permanent withdrawal area and ground water flow would move contaminants onto land that is used for ranching. Since wells have been known to exist in the past for livestock watering, the most likely receptor(s) to contaminated ground water would be livestock. Likewise, the potential would also exist for surface water in Rob Pit to receive contaminant concentrations above background levels due to ground water discharge from the site. The likely receptors to be exposed in Rob Pit would be aquatic life, benthic organisms, wildlife, livestock, and people.

Because of the unique ground water conditions at the Maybell site and the uncertainty associated with speculating about future site ground water conditions, a quantitative risk assessment evaluating future scenarios is not presented.

Nonetheless, in order to be assured that human health and the environment are adequately protected in the future, monitoring of the ground water should continue so that any ground water conditions that change can be evaluated. Already in place is the DOE program for monitoring ground water after the surface remediation is complete. For this program the Long Term Surveillance Plan (LTSP) will be developed for the Maybell site in 1996. The LTSP will describe the monitoring and surveillance program for the Maybell site, including the frequency and location of any ground water monitoring that may be required for ground water protection.

\subsection{LIMITATIONS AND DATAGAPS}

The primary limitation of this risk assessment is the inability to predict the future distribution of contamination. Several mechanisms may be responsible for the lack of downgradient contamination but there are not enough data to distinguish 
among them. These mechanisms are attenuation of contaminants by processes of adsorption, denitrification, precipitation, neutralization processes; a slower than anticipated ground water velocity; and localized contaminant sources located further upgradient from the edge of the plume than indicated by the distribution of the tailings. However, it is not clear whether one or more of these mechanisms is responsible for the lack of contaminants in ground water downgradient of the site. Without this knowledge it is not possible to predict future contaminant distribution including the effects of the projected transient drainage from the disposal cell.

Several datagaps have been identified for the Maybell site which would further characterize the site.

- Ground water monitoring system at and adjacent to the site. There are three areas that do not have adequate monitor well coverage. One of these is the area around the former mill buildings which is a possible contaminant source area. The second area is directly south of the tailings pile between the well cluster containing monitor wells 604, 605 and 645 and monitor well 664 to the east. Three settling ponds were located in this area while the mill was in operation. These ponds are likely sources of contaminants. The third area lies between Rob Pit and the area southwest of the former mill. Additional monitor well coverage would also increase the limited water level database.

- Ground water monitoring system characterizing background water quality. Additional monitor wells to be used to further define background water quality would ensure that the full variability of background has been captured.

- Exact locations of contaminant sources are unknown. Without knowing where the various components of the contaminant plume originated, it is not possible to accurately predict how far they might migrate in ground water.

- Additional characterization of the lithology of the Browns Park Formation would better define the potential for interactions of site-related contaminants and attenuating processes. 


\subsection{LIST OF CONTRIBUTORS}

The following individuals contributed to the preparation of this report.

\begin{tabular}{ll}
\hline Name & Contribution \\
\hline J. Marshall & Toxicologist \\
D. Erskine & Geochemist \\
B. Smith & Hydrogeologist \\
K. Smith & Statistician \\
M. Gawthrop & Document coordinator \\
K. Saar, T. Jackson, A. Holm, & Reviewers \\
B. Brattin & \\
& Graphics \\
D. Tamez & Technical editing \\
L. Sanchez & Text processing \\
\hline
\end{tabular}




\subsection{REFERENCES}

Brookins, D. G., 1988. Eh-pH Diagrams for Geochemistry, New York, Springer-Verlag, 176 p.

Chenoweth, W. L., 1986. Geology and production history of the uranium deposits in the Maybell, Colorado, area: 1986 Symposium, Rocky Mountain Association Geologists, p. 289-292.

Dames and Moore, 1975. "Report of Environmental Studies, Proposed Uranium Heap Leaching Project near Maybell, Colorado, for Uranium Carbide Corporation, “ Job No. 0822-081-06, copy on file in the U.S. Department of Energy, UMTRA Project Office, Albuquerque, New Mexico.

DOE (U.S. Department of Energy), 1994. "Remedial Action Plan and Site Design for Stabilization of the Inactive Mill Tailings Site Maybell Colorado," DOE/AL 6235024F, June 1994, U.S. Department of Energy, UMTRA Project Office, Albuquerque Operations Office, Albuquerque, New Mexico.

EPA (U.S. Environmental Protection Agency), 1989. Statistical Analysis of Ground Water Monitoring Data at RCRA Facilities - Interim Final Guidance, EPA/530-SW-89-026, EPA Office of Solid Waste, Waste Management Division, Washington, D.C.

Evans, A. M., 1987. An Introduction to Ore Geology, Blackwell Scientific Publications, Boston, Massachusetts., $358 \mathrm{p}$.

Freeze, R. A. and J. A. Cherry, 1979. Ground Water, Prentice-Hall, Inc., Englewood Cliffs, New Jersey.

NOAA (National Oceanic and Atmospheric Administration), 1968. U.S. Department of Commerce, National Climatic Center, Asheville, North Carolina.

TAC (Technical Assistance Contractor), 1995a. In preparation. Supplement to the Baseline Risk Assessment of Ground Water Contamination at the Uranium Mill Tailings Sites Near Maybell, Colorado.

TAC (Technical Assistance Contractor), 1995b. Unpublished trip report, Jacobs Engineering Group Inc., UPDCC File Location No. 14.19.7, Albuquerque, New Mexico, September 1995.

TAC (Technical Assistance Contractor), 1992. "Unpublished Field Notes, Maybell, Colorado, Uranium Mill Tailings Site," unpublished report prepared by the Technical Assistance Contractor, Albuquerque, New Mexico, for the U.S. Department of Energy, UMTRA Project Office, Albuquerque Operations Office, Albuquerque, New Mexico. 
TAC (Technical Assistance Contractor), 1990. "Unpublished Field Notes, Maybell, Colorado, Uranium Mill Tailings Site," unpublished report prepared by the Technical Assistance Contractor , Albuquerque, New Mexico, for the U.S. Department of Energy, UMTRA Project Office, Albuquerque Operations Office, Albuquerque, New Mexico.

Thompson \& Associates, 1990. Investigation of Microbial Denitrification in Soils Beneath a Uranium Mill Tailings Pile, Unpublished report prepared for Jacobs Engineering Group Inc., Albuquerque, New Mexico.

URS Company, 1976. "Meteorology Affecting Uranium Tailings Near Maybell, Colorado," unpublished report prepared for Ford, Bacon \& Davis Utah, Inc., Salt Lake City, Utah.

WRCC (Western Regional Climate Center), 1995. Western Regional Climate Center brochure prepared by Atomospheric Sciences Center, Desert Research Institute, Reno, Nevada.

\section{CODE OF FEDERAL REGULATIONS}

40 CFR Part 264, Standards for Owners and Operators of Hazardous Waste Treatment, Storage, and Disposal Facilities, U.S. Environmental Protection Agency (1994).

\section{UNITED STATES CODE}

42 USC $\$ 7901$ et seq., Uranium Mill Tailings Radiation Control Act, 8 November 1978.

42 USC $\$ 7922$ et seq., Amendments Acts of 1988. 